\title{
Islands and scales: a biogeographic survey of reptiles on Kimberley islands, Western Australia
}

\author{
Russell Palmer ${ }^{1 *}$, David J. Pearson'1, Mark A. Cowan' and Paul Doughty ${ }^{2}$ \\ ${ }^{1}$ Department of Environment and Conservation, Science Division, \\ PO Box 51, Wanneroo, Western Australia 6946, Australia. \\ 2 Department of Terrestrial Zoology, Western Australian Museum, 49 Kew St, Welshpool, \\ Western Australia 6106, Australia. \\ *Corresponding author: Russell.Palmer@dec.wa.gov.au
}

\begin{abstract}
The Northern Kimberley region in north-western Australia has high biodiversity and conservation values, including a rich herpetofauna with high levels of endemism. To date, the numerous islands off the coast have been little surveyed. We surveyed 24 of the largest islands along the Kimberley coast for reptiles between 2007 and 2010, to improve our understanding of biogeographical patterns of the region and to locate populations of species that may be threatened by factors including changed fire regimes and Cane Toad invasion. We recorded 79 species of terrestrial reptiles. Species richness ranged from 14 to 32 taxa per island (mean $=22$ ), and tended to increase with island area. Many taxa (36.7\%) were Northern Kimberley endemics, 10 of which are only known from island populations. There were numerous new records for islands, range extensions and the discovery of at least three new taxa. Classification based on species presence/absence data identified several distinct clusters of islands, with geographical location of islands, extent of rugged, rocky habitat and climatic gradients at a regional scale having important influences on reptile communities. The main cluster of nine islands with the greatest species richness, including richness of Northern Kimberley endemics, was located in the high rainfall zone of the north-west Kimberley. Islands in this cluster were also generally larger in size and they were the most rugged. Island clusters in the mostly drier areas to the north and south had less diversity and often different taxa to the north-west Kimberley cluster. The remaining islands-Adolphus, Sir Graham Moore, Mary and Kingfisher-were all distinct in the classification analysis. The Kimberley islands harbour unique taxa and reptile assemblages, as well as numerous species known to be vulnerable to Cane Toad toxins and, as such, are important conservation refuges. Careful consideration is required of any proposals to develop the islands, and ongoing surveillance and quarantine is necessary to prevent the introduction of invasive species.
\end{abstract}

KEYWORDS: conservation, endemic herpetofauna, funnel traps, species assemblages

\section{INTRODUCTION}

Almost a third of the islands found within Australia's territorial waters lie off the remote Kimberley coast in north-western Australia (Conservation Council of Western Australia [CCWA] 2010). The majority of these islands are continental or land-bridge islands that were separated from the mainland by rising sea levels following the end of the last glacial maximum in the late Pleistocene around 19,000 years ago (De Deckker and Yokoyama 2009). Sea levels stabilised at around their current levels approximately 6000 years ago ( $\mathrm{O}^{\prime} \mathrm{C}$ onnor 1999). The estimated 2633 islands along the Kimberley coast range in size from small rocky islets to islands up to 18,929 ha, many of which are topographically complex (CCWA 2010). Most are near-shore $(<30$ $\mathrm{km})$, and few of the 20 largest islands ( $>1000 \mathrm{ha})$ are more than $5 \mathrm{~km}$ from the coast. Only four northern Kimberley islands are included in Western Australia's system of protected areas (CCWA 2010).

The Northern Kimberley IBRA region (Thackway and Cresswell 1995; hereafter referred to as 'Northern Kimberley') incorporates most of the islands in the Kimberley region. It is recognised nationally as a centre of high reptile diversity and endemism (Cracraft 1991; How and Cowan 2006; Powney et al. 2010), despite the lack of systematic 
biological surveys of the reptile fauna of the region (McKenzie et al. 2009). In particular, the higher rainfall zone of the north-western Kimberley (>1000 mm p.a.) has remarkable levels of local endemism (e.g. Oliver et al. 2010, 2012). The survey and description of reptiles in the Kimberley has lagged behind that of the mammal and bird fauna, with around $50 \%$ of reptiles in the region only formally described since the 1970s. New reptile taxa continue to be discovered and described, both by traditional morphological techniques (e.g. Horner 2005, 2009; Bauer and Doughty 2012) and molecular techniques, with the recognition of numerous new taxa (Horner 2007; Pepper et al. 2011a; Doughty et al. 2012a); cryptic taxa (Oliver et al. 2010, 2012; Melville et al. 2011; C. Moritz, pers. comm.) and restricted range taxa (Oliver et al. 2010, 2012; Bauer and Doughty 2012).

Upon isolation, the land-bridge islands of the Kimberley presumably carried subsets of the assemblages of species on the adjacent mainland based on the habitats present before isolation. Island biogeographic theory predicts that landbridge islands will undergo a period of species loss following their separation from the mainland (MacArthur and Wilson 1963). Yet, despite the loss of diversity, land-bridge islands remain species-rich in comparison with newly formed (e.g. volcanic or coral rubble) oceanic islands of similar size, since species must successfully disperse over water, and equilibrium is reached by adding species over time (Case 1975, 2002).

In tropical regions such as the Kimberley, the opportunities for over-water colonisation of islands by reptiles are enhanced by extreme rainfall events (including cyclones), warm surface waters and an abundance of vegetation that can form rafts (Calsbeek and Smith 2003). River systems along the Kimberley coast produce extensive freshwater plumes in their tidal lower reaches during the summer monsoon season and, combined with strong currents (Cresswell and Babcock 2000), would conceivably increase the chances of unaided dispersal and prolong the survival of swimming or rafting herpetofauna (e.g. Woinarski et al. 2011).

Human activities have played a role in altering biogeographical patterns of reptiles on islands in many parts of the world through extinctions caused by the accidental or deliberate introduction of non-native and invasive species (mostly predators) and through the destruction of habitat (Richman et al. 1988; Ficetola and Padoa-Schioppa 2009; Fattorini 2010). Aboriginal fire management on the Kimberley islands, which was noted by early navigators and explorers (Vigilante 2001), may have influenced the present-day reptile faunas of the islands through regular burning of fireprone savannah woodlands or by the modification of microhabitats and refugia (Woinarski et al. 1999). The remoteness, harsh climate and lack of surface freshwater for much of the year has discouraged European settlement historically (Crawford 2001). Although mining tenements currently cover a considerable proportion of the islands, only Cockatoo and Koolan islands have been extensively mined. As a result, few islands are known to harbour introduced mammals or reptiles (CCWA 2010). Increased expansion of the iron ore and oil and gas sectors in the region is proposed and, apart from impacts on fauna from the associated habitat loss, increases the risk of introducing non-native predators, weeds and pathogens to the islands.

Perhaps the most imminent risk to Kimberley island herpetofauna is the invasion of the exotic Cane Toad (Rhinella marina) through the Northern Kimberley. The Cane Toad is known to affect predatory species that eat frogs, such as snakes, goannas and large skinks (see Shine 2010 for a review). Death Adders (Acanthophis praelongus), Blue-tongue Skinks (Tiliqua scincoides) and a number of goannas, especially Varanus $p$. panoptes and $V$. mertensi, are known to be particularly susceptible to toxic poisoning following the ingestion of toads (Smith and Phillips 2006; Doody et al. 2009; Price-Rees et al. 2010; Shine 2010). Although some population recoveries on the mainland have been noted (Phillips et al. 2009), recovery in island populations, with their small population size and limited genetic variation, may be less likely.

Prior to this study, there were around 60 taxa known from the islands (Western Australian Museum [WAM] specimen database). These taxa were detected during previous biological surveys (Smith and Johnstone 1978; How et al. 2006), other localised surveys (McKenzie et al. 1995; Maryan and Reinhold 2009) and the Kimberley rainforest survey (Kendrick and Rolfe 1991; summarised in Table 1). Most of this survey effort has focused on the larger islands of the Bonaparte Archipelago and Koolan Island. Apart from Koolan, which has been mined since the 1960s, reptiles have generally been a minor component of previous biological survey programs, with limited use of specialised reptile traps. A comprehensive reptile inventory (39 taxa) collated over the past 50 years by residents and zoologists on Koolan Island (2509 ha) provides a comparative benchmark for our survey (McKenzie et al. 1995; Maryan and Reinhold 2009). While these surveys have produced reptile species lists for islands, there have been no analyses of island reptile assemblages in relation to environmental attributes.

The study of the herpetofauna on Kimberley islands is intrinsically interesting to understand biogeographic patterns, to identify islands of 
particular conservation importance and to allow comparison with other studies [e.g. Woinarski et al. (1999) on Arnhem Land islands], which may have benefits for predicting the impact of disturbances such as changed fire regimes or climate change on island faunas. The islands of the Kimberley coast are likely to contain important refugial habitats, free of many of the threatening processes that may affect mainland reptile communities. Island reptile populations may also have diverged morphologically and ecologically from mainland populations, in response to different resource or environmental conditions and/or a changed array of competing species (e.g. Case 2002).

A biological survey of 24 of the larger Northern Kimberley islands (Kimberley Island Biodiversity Survey - KIBS) was undertaken between 2007 and 2010 (Gibson and McKenzie 2012a). Here we present the results of the terrestrial reptile component of this survey. Our aims were to document taxa occurring on the islands, evaluate similarities in communities among islands, examine patterns of island assemblages in relation to environmental factors and compare these patterns with those seen elsewhere, including the mainland. Furthermore, we aimed to identify islands containing species susceptible to mainland threats, such as the invasion of Cane Toads.

\section{METHODS}

\section{STUDY AREA}

We surveyed 24 islands (ranging from 300-18,929 ha) located between King Sound (near Derby) in the south-west Kimberley and Cambridge Gulf (near Wyndham) in the east Kimberley, spanning an arc of approximately $800 \mathrm{~km}$ along the coast (Figure 1). Surveyed islands included most of the larger, better known islands that have established European names, but excluded those with active mining (Koolan and Cockatoo islands) and mining exploration (Irvine). Champagny Island was not surveyed as it had been recently burnt. Islands

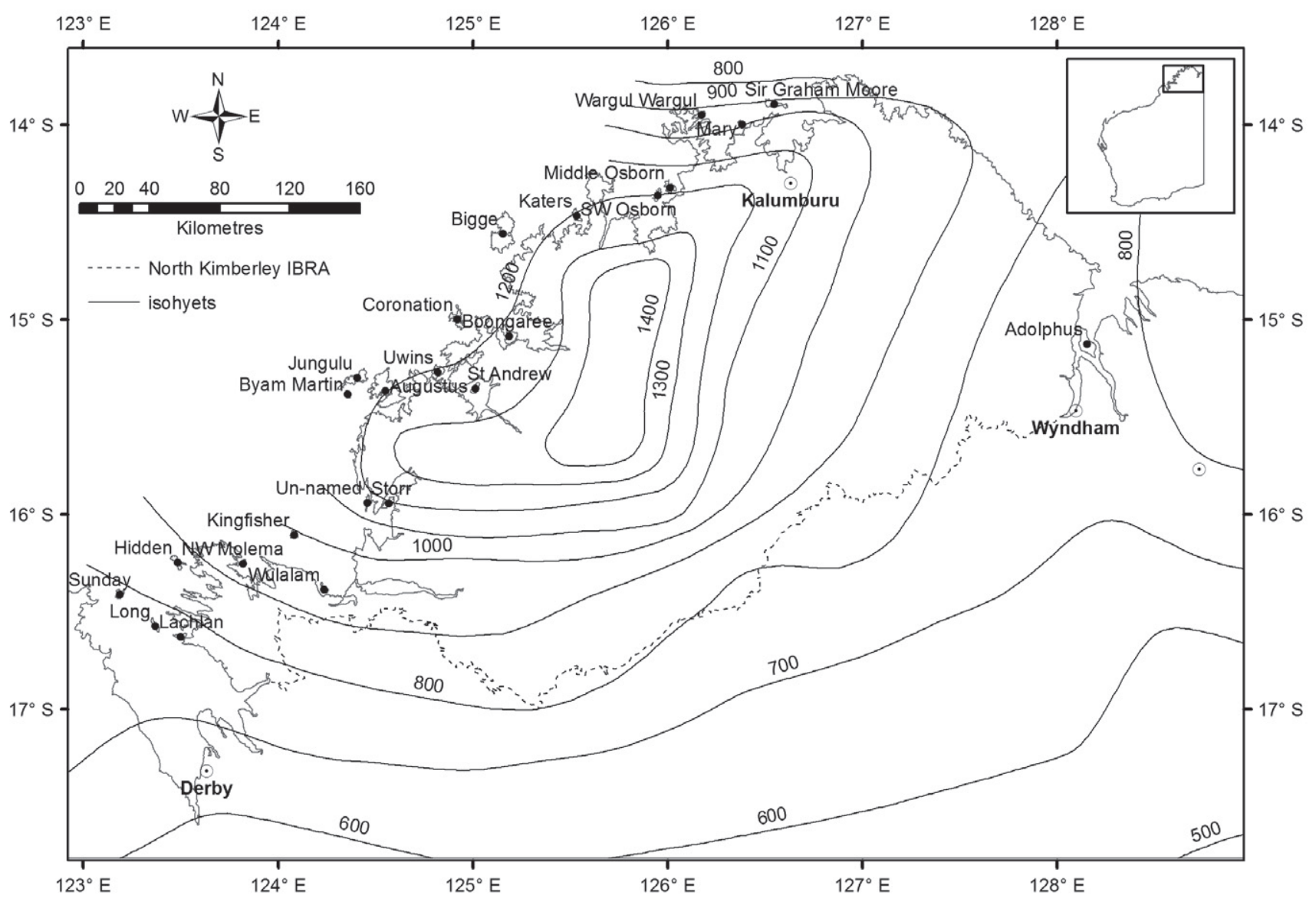

FIGURE 1 Map of study area in the Kimberley region of Western Australia showing the location of sampled islands, rainfall isohyets (solid lines) and Northern Kimberley IBRA region (broken lines). 
sampled for the first time include Adolphus, Mary, Wargul Wargul (sometimes called Woku Woku), an un-named island adjacent to Lizard Island (called Un-named here), Storr, another un-named island in Talbot Bay (called NW Molema here) and Wulalam. All islands we surveyed were either Unallocated Crown Land subject to native title claim or gazetted Aboriginal Reserves.

We selected large islands as they were likely to contain more diverse assemblages of vertebrates, especially those with mammals that were threatened with extinction on mainland Australia (Gibson and McKenzie 2012a, 2012b). Islands were also chosen to provide wide geographic spread and to contain representative areas of as large a range of geological surfaces (and by inference, vegetation communities and habitat types) as possible. All of the surveyed islands fall within the Northern Kimberley IBRA region, except for Sunday Island, which is technically within the Dampierland IBRA region (Thackway and Cresswell 1995). Geologically, Sunday Island is more closely aligned with the Northern Kimberley than Dampierland, reflecting the generalised nature of the IBRA boundaries. Adolphus Island in Cambridge Gulf is located in the eastern extremity of the Northern Kimberley bioregion (Figure 1).

\section{CLIMATE}

The Kimberley region has a tropical, monsoonal climate with marked, wet summers and dry winters, known colloquially as 'the Wet' (typically October to March) and 'the Dry' (April to September). Between these two broadly-defined seasons are transitional periods, so that in October and November, dry easterly winds are increasingly replaced by convective westerlies, with the onset of the monsoon typically occurring between late November and early January (Wheeler and McBride 2005; Bowman et al. 2010). Extreme weather events such as tropical cyclones and severe thunderstorms are common during the wet season, leading to high variability in rainfall among years (Wheeler and McBride 2005). Another characteristic of Australia's monsoonal tropics is a strong latitudinal gradient of rainfall (Bowman et al. 2010). While this pattern is apparent in the Northern Kimberley, it is confounded by a zone of high rainfall in the north-west of the region, where mean annual rainfall exceeds $1200 \mathrm{~mm}$ (Figure 1). Thus, rainfall is generally lowest on those islands in the north-east, north and south-west of the Kimberley, and highest on islands located in the north-west (Table 1). Apart from the wet season, freshwater is limited on most islands. Augustus and Bigge are probably the only islands with near-permanent creeks. Average temperatures range from a daily maximum of $33^{\circ} \mathrm{C}$ in January to a night time minimum of $15^{\circ} \mathrm{C}$ in July (Bureau of Meteorology 2012).

\section{GEOLOGY AND SOILS}

The geology of the Kimberley islands reflects that of the adjacent mainland, although even the largest islands contain only two to five geological units (Burbidge and McKenzie 1978). The Kimberley landscape is stable, deeply weathered, and one of great antiquity, with Precambrian basement rocks (Burbidge and McKenzie 1978; Bowman et al. 2010). The region's geomorphology is dominated by exposed Proterozoic sandstones which form abrupt escarpments, cliffs and rocky slopes often strewn with massive boulders and are intruded by Proterozoic volcanics (Start et al. 2007; Bowman et al. 2010). In some areas, superficial Cenozoic sediments overlie Precambrian bedrock, and more recent Quaternary sediments occur in coastal areas. While the maximum elevation on the islands is generally low (Appendix 1), rocky areas are typically rugged and extensively dissected. Soils on the islands are typically shallow to skeletal, with shallow sand sheets found on the broad, undissected uplands (Start et al. 2007). Detailed descriptions of the dominant geological strata, landforms and associated vegetation found on the surveyed islands are presented in Gibson and McKenzie (2012a). A summary of geological units occurring on islands is presented in Table 1.

\section{VEGETATION}

The dominant vegetation of the islands is open savannah woodlands with a canopy of Eucalyptus spp. over an understorey of grasses and scattered broadleaf shrubs (Beard 1979; Bowman et al. 2010). Vegetation varies structurally and floristically with substrate, topography and rainfall (Beard 1979; Start et al. 2007). Areas with more fertile soils, greater water availability during the dry season (such as along perennial streams) and protected from fire support small pockets of monsoon rainforest. Littoral rainforest is found at some coastal sites, while more diverse rainforests are found around the base of sandstone cliffs, especially when volcanic soils are present (Burbidge and McKenzie 1978; Bowman et al. 2010). Coastal dune systems support grasslands of beach spinifex (Spinifex longifolius), while nutrient-poor sandy soils and rocky plateaus are dominated by Triodia spp. with occasional trees. Extensive low, closed mangrove forests occur in large sheltered bays (Burbidge and McKenzie 1978).

\section{HUMAN INFLUENCES}

Indigenous people made extensive use of the Kimberley islands, using the tides and currents to raft to and from the mainland $\left(\mathrm{O}^{\prime} \mathrm{Connor} 1999\right.$; Crawford 2001; Vigilante et al. 2013), although specific information on the use of islands we 


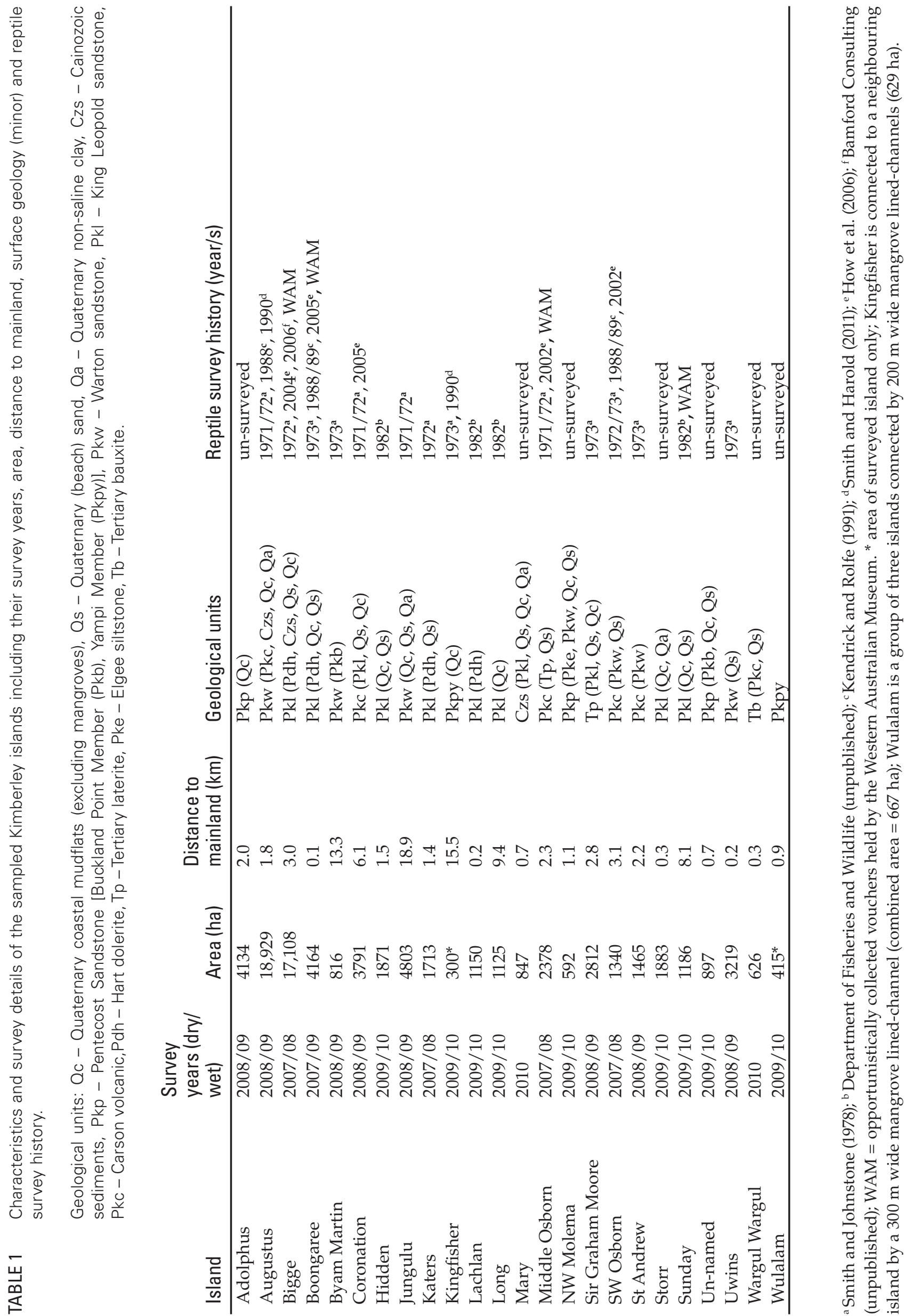


surveyed is limited. Traditional management of these islands by Aboriginal people involved the use of fire, which is likely to have altered vegetation structure and composition in some areas. Currently, none of the surveyed islands are inhabited, although Nilagoon outstation on Sunday Island and a fishing shack on Lachlan Island are used for short visits. The use of islands for pastoral purposes was negligible with only Sunday Island (goats, cattle and pigs) and Sir Graham Moore Island (goats and pigs) having a history of introductions. Of these, only feral pigs remain on Sir Graham Moore Island and at low density (RP, pers. obs. 2007). The Black Rat (Rattus rattus) was recorded at the Sunday Island mission in 1915 (Basedow 1918) and near the Nilagoon outstation also on Sunday Island in 1982 (Abbott and Burbidge 1995).

\section{SAMPLING}

Survey sites on each island were selected by examination of geological and topographic maps, Google Earth $^{\mathrm{TM}}$ imagery and a reconnaissance flight in a light aircraft. Selected sites were assessed and given clearance by the Traditional Owners so that culturally sensitive areas were avoided. Each survey site encompassed as many of the major habitat types as possible within walking distance of a central camp location. Larger islands (Adolphus, Augustus, Bigge, Coronation, Jungulu, Middle Osborn and Sir Graham Moore) had two survey sites to enable better coverage of environmental variation on these islands. A total of 31 survey sites were sampled on the 24 islands over four dry (May-August) and three wet (February) seasons between 2007 and 2010 (Table 1). Dry season surveys were conducted by three teams each made up of two vertebrate zoologists (mammalogist and herpetologist), a botanist, a terrestrial malacologist and one or two Traditional Owners. Each survey site was sampled over six nights, with four (occasionally three) trapping transects established in the major habitat types of the island. Baited aluminium box traps and cage traps set chiefly for mammals were established first along each transect (see Gibson and McKenzie 2012b). Collapsible double-ended funnel traps (75 x $18 \times 18 \mathrm{~cm}$, entrance diameter $4 \mathrm{~cm}$; Coast-to-Coast Vermin Supplies, Baldivis, Western Australia) were used extensively to sample terrestrial reptiles. They were arranged along two trapping lines installed in representative habitat patches along each trapping transect and set for four or five nights. Each funnel trap line consisted of two or three pairs of funnel traps, spaced evenly alongside an aluminium flywire drift fence that varied in length from 15-30 m depending on topography. Drift fences were $25 \mathrm{~cm}$ in height with a $5 \mathrm{~cm}$ folded 'foot' at the base that was buried with soil or held in place with small rocks. Funnel traps were checked every morning and in afternoons if temperatures and/ or capture rates were high. Funnel traps exposed to the sun were covered with vegetation and other materials to shade them.

In addition to the trapping, we undertook active diurnal and nocturnal searches. Diurnal search methods included visual searches for basking reptiles in sunny patches on tree trunks and rocks, slowly walking along transect paths, raking of soil and leaf litter, peeling loose bark off trees, log rolling and rock turning (all logs and rocks were returned to their original position). Headtorching for nocturnal species was conducted on most nights, for 1-3 hours. Reptiles found by searching were usually captured by hand. Diurnal and nocturnal searches were not confined to transects; we also selected specific habitats and landscape features favoured by reptiles, such as caves, freshwater bodies (usually rock pools), cliffs and rock outcrops in an effort to encounter as many species as possible.

Survey sites were revisited during the wet season for a single night, except for those on Mary and Wargul Wargul islands due to time constraints and the second site on Middle Osborn Island due to bad weather. Wet season surveys were conducted by helicopter and/or charter boat. During these surveys, a single herpetologist (2008) or two herpetologists $(2009,2010)$ undertook 3-5 hours of head-torching starting soon after dusk. The surveys primarily focussed on frogs, so active searches were concentrated in the wetter habitats on each island (Doughty et al. 2012b). Apparent gaps in the reptile species lists for each island were determined prior to the surveys, and specific searches made for these species. Reptile vouchers and tissue samples were collected in accordance with our animal ethics permit and lodged in the WAM.

\section{ADDITIONAL REPTILE RECORDS}

In addition to our survey, we extracted species lists from the published literature, the zoological collections database of the WAM and NatureMap (http://naturemap.dec.wa.gov.au) for all of the Kimberley islands and the adjacent Northern Kimberley mainland. The survey history of terrestrial reptiles for the islands we sampled is summarised in Table 1. There have been three major biological surveys. The first was undertaken by the Department of Fisheries and Wildlife (DFW) during the dry seasons of 1971, 1972 and 1973. They visited 27 islands in the north-west Kimberley, collecting reptiles mostly through active search techniques and incidental captures in traps set for mammals (Smith and Johnstone 1978). Second, DFW surveyed a further 12 islands in the Buccaneer Archipelago in June 1982. Greater effort 
was directed towards reptiles during this survey, including extensive use of head-torching and the use of some pitfall traps. Although not published, voucher specimens were lodged with the WAM and the original data sheets were examined by one of us (RP) for observational records. Third, How et al. (2006) surveyed 35 islands during three expeditions to the Bonaparte Archipelago between 2002 and 2005. They targeted common and widespread reptile species, sampling mostly via diurnal active searches in litter and fallen timber as well as hand foraging beneath rocks and logs.

\section{REPTILE TAXONOMY AND NOMENCLATURE}

Nomenclature and taxonomy for named species follows the 'Checklist of the Terrestrial Vertebrate Fauna of Western Australia' provided by the WAM, current as of January 2013. We made several changes and additions to the checklist. To distinguish between large and small forms of the Pseudechis australis complex in the Kimberley (Kuch et al. 2005), P. weigeli was used for the smaller $(<1.2$ $\mathrm{m}$ in body length) and slender species occurring in the north-western tropics (Wilson and Swan 2010).

The taxonomic resolution of some reptile groups in the Kimberley is known to be poor (e.g. Gehyra; Sistrom et al. 2009; Doughty et al. 2012a), while others have recently been shown to harbour cryptic taxa (e.g. Diporiphora - Smith et al. 2011; Crenadactylus - Oliver et al. 2010, 2012; Heteronotia - C. Moritz, pers. comm.; Eremiascincus - PD, S. Mecke, S.C. Donnellan, unpublished data; Ramphotyphlops - PD, R. Ellis, J. Marin, N. Vidal, S.C. Donnellan, unpublished data). Tissue samples and/or vouchers belonging to the genera Diporiphora, Crenadactylus, Gehyra, Heteronotia and Eremiascincus that were collected during the survey have been included in recent and ongoing molecular studies and/or taxonomic revisions. New taxa identified in these studies have been assigned coded names provided by publications (e.g. Crenadactylus Kimberley C; Oliver et al. 2010) or by researchers (e.g. Heteronotia binoei NWK; C. Moritz, pers. comm.). The small arboreal skinks Cryptoblepharus metallicus and C. ruber were difficult to reliably differentiate morphologically from each other (Horner 2007) and were combined for the analysis (labelled C. metallicus/ruber). For clarification, Diporiphora bennettii is a small sandstone rock-dwelling dragon, endemic to the north-west Kimberley and adjacent islands (PD, pers. obs.). There is another undescribed species frequently called $D$. bennettii, which is more widely distributed in the Kimberley, called 'Diporiphora aff. bennettii' here. Smith et al. (2011) identified a divergent genetic lineage within ' $D$. magna' from the Northern Kimberley, which we refer to here as D. 'margaretae' (an available name currently in synonomy of D. magna).

\section{ANALYSIS}

We used a multivariate statistical approach to identify reptile community structure between island pairs and to assess the contribution of a number of environmental variables to the observed patterns. A similarity matrix for the 24 islands based on reptile species occurrence was produced using the resemblance routine in PRIMER v6 (Clarke and Gorley 2006). The default BrayCurtis distance coefficient was used which, when applied to occurrence data, as was the case here, is equivalent to the Sørensen's similarity coefficient. The Sørensen's coefficient gives double weight to double presence, since the presence of a species is more informative than its absence (Legendre and Legendre 1998). This coefficient has frequently been used in island biogeographic analysis (e.g. How and Kitchener 1997; Hice and Schmidly 2002; Pietsch et al. 2003). The resultant association matrix was clustered using the unweighted pair group method with arithmetic mean (UPGMA). Indicator species characterising each group (or cluster) of islands identified in the above analysis were determined following Dufrêne and Legendre (1997) using PCOrd (McCune and Mefford 1999). Indicator species values (ISA) are high when individuals of one taxon were found on all islands that formed a cluster, but were not recorded on islands in any of the other clusters. Widely distributed taxa found on most islands across clusters or restricted range endemic taxa confined to a few islands within a cluster generally yielded low ISA values (see Dufrêne and Legendre 1997). Since it is often difficult to interpret biogeographical relationships from a dendrogram (Fattorini 2010), the defined clusters were overlain on a non-metric multidimensional scaling ordination (nMDS), which preserved relative distance relationships between all points.

A matrix of island attributes, which incorporated both ordinal and quantitative environmental variables, including interpolated mean climatic variables derived from BIOCLIM (Houlder et al. 2000) was examined against the island association matrix using the BEST function in PRIMER. The BEST routine searches for individual and combinations of variables that produce the highest Spearman rank correlation with a sample-based association or resemblance matrix. Prior to this analysis, a Pearson correlation matrix for all environmental variables was calculated and where any pair of variables had a correlation of $\geq 0.8$, one of the variables was excluded from the matrix. The final list of variables that were used in the analysis is presented in Appendix 1. These data were normalised prior to analysis and the default settings of a maximum of five trial variables and the 10 best results was chosen in the BIOENV function. Statistical significance was tested using 99 


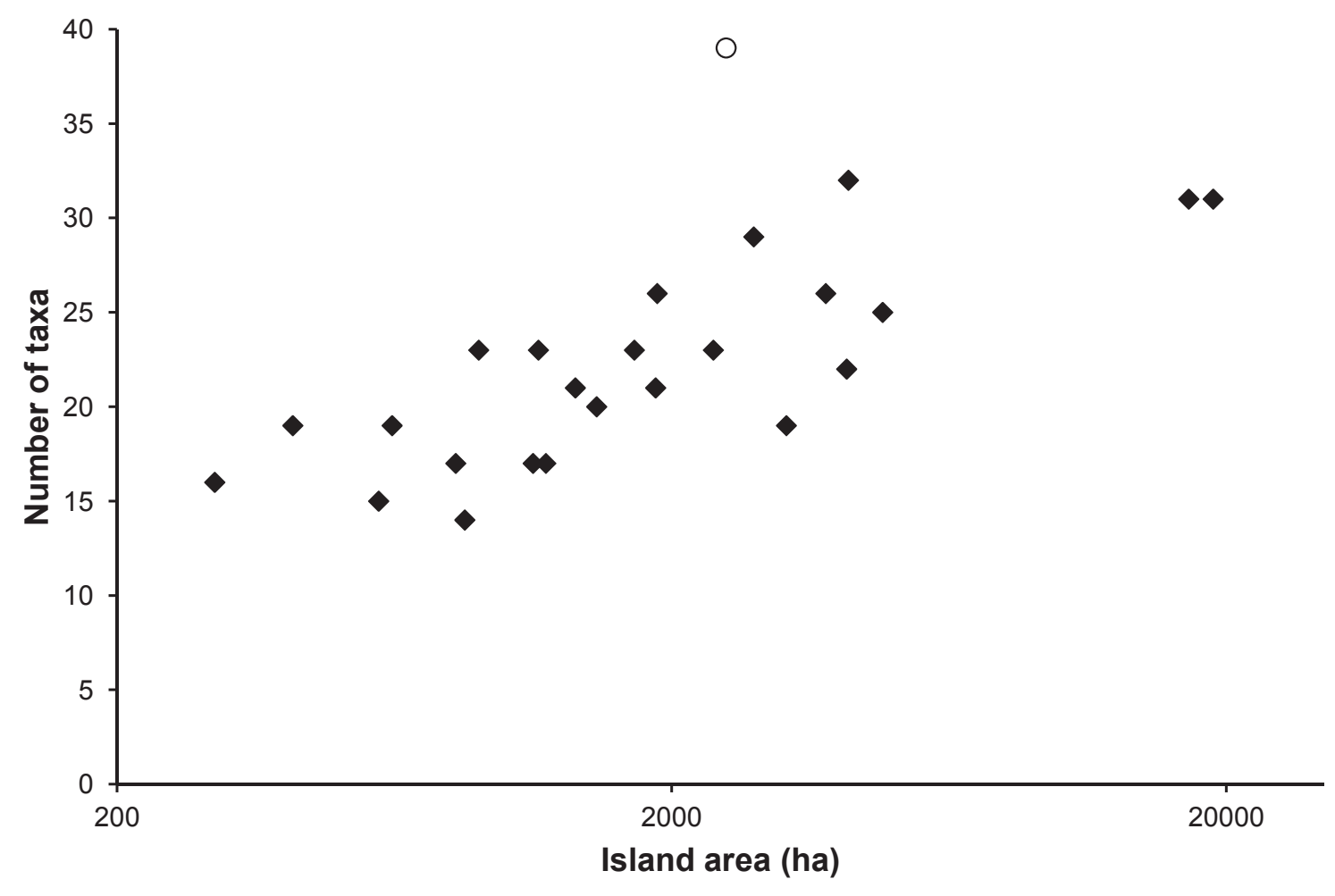

FIGURE 2 The relationship between reptile species richness and area for the 24 sampled Kimberley islands. Logarithmic scale for area axis. The open circle represents the extensively sampled Koolan Island (not sampled during our survey).

trials in the permutation test.

The degree of spatial structure (or distance decay) in the composition of the reptile taxa was examined using partial Mantel tests. A Euclidean distance matrix was calculated for geographical distance based on the geographical coordinates of the midpoints of the islands. Partial Mantel tests were then used to examine the relationship between species similarity and each of the environmental attributes (after calculating Euclidian distance matrices for each attribute), while holding the geographic distance matrix constant. The significance of the relationships between the matrices was examined using a Monte-Carlo procedure with 999 permutations. Partial Mantel tests were performed within the $\mathrm{R}$ statistical computing package ( $\mathrm{R}$ Development Core Team 2009).

Permutated species accumulation curves were produced in PRIMER using the islands as samples. The Chao 2 and Jackknife 2 species richness estimators were used as they are considered to give a meaningful view of species richness where only occurrence data are available (Magurran 2004).

\section{RESULTS}

\section{REPTILE SPECIES AND RICHNESS ON ISLANDS}

We found 79 species of terrestrial reptiles representing 10 families on the 24 islands sampled. The species counts for families were as follows: Agamidae 5, Diplodactylidae 10, Gekkonidae 15, Pygopodidae 2, Scincidae 22, Varanidae 6, Typhlopidae 3, Boidae 5, Colubridae 2, Elapidae 9 (Appendix 2). Species richness per island varied from 14 (Mary) to 32 (Boongaree) taxa (mean = 22.0 $\pm 5.2 S D)$ and increased with increasing island area $\left(\mathrm{R}^{2}=0.45 ; P<0.001\right.$; Figure 2$)$.

The skink Ctenotus inornatus was ubiquitous, occurring on all 24 islands. Other species found on many surveyed islands were Cryptoblepharus metallicus/ruber (22 islands), Delma borea (21), Carlia triacantha (20), Eremiascincus isolepis sp. A (20) and Pseudechis weigeli (20). Some high trophic level species (e.g. Antaresia childreni, Liasis olivaceus, Varanus glauerti and V. glebopalma) were also found on between 15 and 18 of the islands (Appendix 2). In contrast, 19 species were recorded on only a 
single island, and 11 species from only two islands each.

We recorded 23 new records of taxa for the islands we surveyed, and 17 of these were also additions to the known reptile fauna of the Northern Kimberley islands. At least three new species have been identified from the islands, including two species of Crenadactylus, one each from Adolphus and Katers islands, and a blind snake (Ramphotyphlops sp. B) from Storr Island. Three taxa listed on the Department of Environment and Conservation (DEC) (2010) priority list were captured (http://www.dec.wa.gov.au/managementand-protection/threatened-species/listing-ofspecies-and-ecological-communities.html): Morelia spilota variegata (Mary Island), Ctenotus decaneurus yampiensis (Storr Island) and Lerista kalumburu (Sir Graham Moore and Mary islands).

Numerous range extensions were documented. Previously, Crenadactylus Kimberley C and Crenadactylus Kimberley E were only known from a single island each (Oliver et al. 2010); however, we found these taxa on three and four further islands, respectively (Oliver et al. 2012). Our sampling also clarified the island distributions and taxonomic boundaries of numerous other taxa, while the collection of voucher specimens and tissues is contributing to current taxonomic revisions. Ongoing molecular and taxonomic research of the Kimberley reptile fauna has recognised new taxa within the genera Eremiascincus, Gehyra and Heteronotia and the aforementioned Crenadactylus. Many of these newly identified Kimberley taxa were also found to have island populations based on specimens collected during our survey.

\section{SAMPLING EFFECTIVENESS}

Our survey was the first time funnel traps have been used extensively in reptile sampling on the Kimberley islands. We caught over 1300 individuals of 49 reptile taxa in funnel traps. Most of these captures were common terrestrial species of skinks and geckos that were also detected via active foraging methods. Elapid snakes, however, were mostly detected using funnel traps, with 93 of the 127 records across nine species resulting from funnel trap captures, including 53 of 55 records of Demansia papuensis. The only elapid we recorded from the islands, but not in a funnel trap, was Acanthophis praelongus. Four taxa (Lerista greeri, Ctenotus robustus, Cryptophis pallidiceps and Pseudonaja mengdeni) were only recorded in funnel traps.

General diurnal and nocturnal active foraging techniques were the most productive sampling techniques for detecting species, resulting in records for 70 taxa. We also captured 12 taxa in aluminium box traps and cage traps set for mammals. Some of these incidental captures did provide unique records at the island level, particularly those of Varanus acanthurus.

Curves for the Chao2 and first order Jackknife estimators predicted a total of 93 and 97 species, respectively. This suggests that while our sampling had accounted for $81-85 \%$ of expected species, with continued sampling of these islands, or with an increased pool of islands to sample, at least a further 14-18 species might have been detected by our survey.

As a measure of sampling adequacy, we compared the taxa captured during this survey with previous island surveys (Table 2). Of the 24 surveyed islands, 17 had been sampled previously. We recorded 51 of the 56 species known from these 17 islands, as well as numerous additional taxa (Table 2). The five species we did not detect were all known from one or two previous records: Ramphotyphlops sp. B (Augustus Island), Pseudothecadactylus cavaticus and Varanus gouldii (Boongaree), Morelia carinata (Bigge), and Carlia munda (Sir Graham Moore). In the first survey season, we failed to record between 6 and 13 of the known species for South West Osborn, Bigge and Boongaree, which had the richest known species lists, apart from Augustus (Table 2). In most cases, these were uncommon higher order predators (snakes and goannas), habitat specialists or rare and cryptic species. During the subsequent survey seasons we detected most of the known species from previously surveyed islands (Table 2).

Although additional species were still detected on the last full survey day (day 5) during the dry season at 25 of the 31 survey sites and on the last morning at nine of these sites, examination of the 31 site accumulation curves showed that all had approached or reached an asymptote. Extra species were found on 14 of the 22 islands surveyed during the wet season, averaging 1.1 extra species $( \pm 1.1 S D$; range 0-3) per island. Boiga irregularis (4 islands) and Antaresia childreni (3) were the most common additions among the 25 extra island records from the wet season sampling. Pogona microlepidota was only found in the wet season during our survey, with new records for Katers and Boongaree. Goanna tracks and scats were observed on Mary and Wargul Wargul islands, but none were caught or observed.

Other apparent 'gaps' visible in the species matrix are for a number of widespread and relatively easy to detect taxa, which indicates probable false absences (Appendix 2). For example, Gehyra aff. nana sp. A is a terrestrial species that prefers areas of sheet sandstone and was generally easy to find by head-torching. This species was found on most islands from Katers to Sunday, but it was probably missed on the sandstone islands of Uwins and Un- 
TABLE 2 A comparison between the number of terrestrial reptile taxa detected on islands in the Kimberley during the current Kimberley Island Biodiversity Survey (KIBS) and those detected during previous surveys.

\begin{tabular}{llllll} 
Island & $\begin{array}{l}\text { Taxa detected in } \\
\text { previous surveys }\end{array}$ & $\begin{array}{l}\text { Taxa detected } \\
\text { by KIBS }\end{array}$ & $\begin{array}{l}\text { Island } \\
\text { total }\end{array}$ & $\begin{array}{l}\text { Taxa added } \\
\text { by KIBS }\end{array}$ & $\begin{array}{l}\text { Known taxa not } \\
\text { detected by KIBS }\end{array}$ \\
\hline Augustus & 21 & 27 & 31 & 10 & 4 \\
Bigge & 23 & 24 & 31 & 8 & 7 \\
Boongaree & 25 & 19 & 32 & 7 & 13 \\
Byam Martin & 6 & 17 & 17 & 11 & 0 \\
Coronation & 9 & 26 & 26 & 17 & 0 \\
Hidden & 12 & 20 & 21 & 9 & 1 \\
Jungulu & 9 & 23 & 25 & 16 & 2 \\
Katers & 6 & 23 & 23 & 17 & 0 \\
Kingfisher & 4 & 16 & 16 & 12 & 0 \\
Lachlan & 12 & 22 & 23 & 11 & 1 \\
Long & 12 & 15 & 17 & 5 & 2 \\
Middle Osborn & 10 & 23 & 23 & 13 & 0 \\
Sir Graham Moore & 13 & 27 & 29 & 16 & 2 \\
St Andrew & 6 & 18 & 20 & 14 & 2 \\
SW Osborn & 16 & 15 & 21 & 5 & 6 \\
Sunday & 10 & 16 & 17 & 7 & 1 \\
Uwins & 6 & 19 & 19 & 13 & 0 \\
\hline
\end{tabular}

named where suitable habitat was observed from the helicopter but could not be reached from the survey sites.

\section{REPTILE ASSEMBLAGES}

Four distinctive island clusters and four single island outliers were identified by nMDS, with groups cut at $60 \%$ similarity (Figure 3 ). The four clusters were grouped according to the geographical positioning of islands (Figure 4). Most of the islands were within the three largest clusters. The largest cluster (C) contained 11 predominantly rugged sandstone (King Leopold and Warton sandstones) islands situated in the high rainfall zone $(>1000 \mathrm{~mm})$ of the north-west Kimberley. The four indicator species for this cluster are also all regional endemics, and included G. multiporosa, Carlia johnstonei, Gehyra xenopus and Amalosia obscura (Table 3). The primarily volcanic islands of South West Osborn, Middle Osborn and Wargul Wargul formed cluster D (Figure 3). The Osborn islands fall within the high rainfall zone and Wargul Wargul is in the slightly lower rainfall (900-1000 mm) area further to the north of cluster C (Figures 1 and 4). Indicator species were Gehyra nana, Heteronotia binoei NWK and Cryptoblepharus megastictus (Table 3). The King Leopold sandstone islands of Hidden, Lachlan, Long and Sunday in the drier $(<850 \mathrm{~mm})$ south-west of the study area formed cluster A. Indicator species for this cluster included Varanus glebopalma and Notoscincus ornatus (Table 3).

The remaining five clusters only contained one or two islands. Cluster B contained two islands, Wulalam and NW Molema, which are located on the northern side of Yampi Peninsula and receive about $900 \mathrm{~mm}$ rainfall annually. Indicator species were Demansia quaesitor, Carlia amax, Acanthophis praelongus and Crenadactylus Kimberley E (Table 3). The remaining four islands (Adolphus, Sir Graham Moore, Mary and Kingfisher) did not cluster with any others at the $60 \%$ similarity level and are represented as single points in the ordination space (Figure 3). Adolphus Island is located in the eastern Kimberley, distant from the other islands surveyed, and contained four taxa not found on other islands. Sir Graham Moore is a relatively large and species-rich (29 taxa) island with a diverse array of habitats, including extensive sandy areas (Table 1). The nearby Mary Island is almost entirely Quaternary sand with very little outcropping rock. Mary is species-poor (14 taxa), lacking many of the saxicoline species found on Sir Graham Moore but 


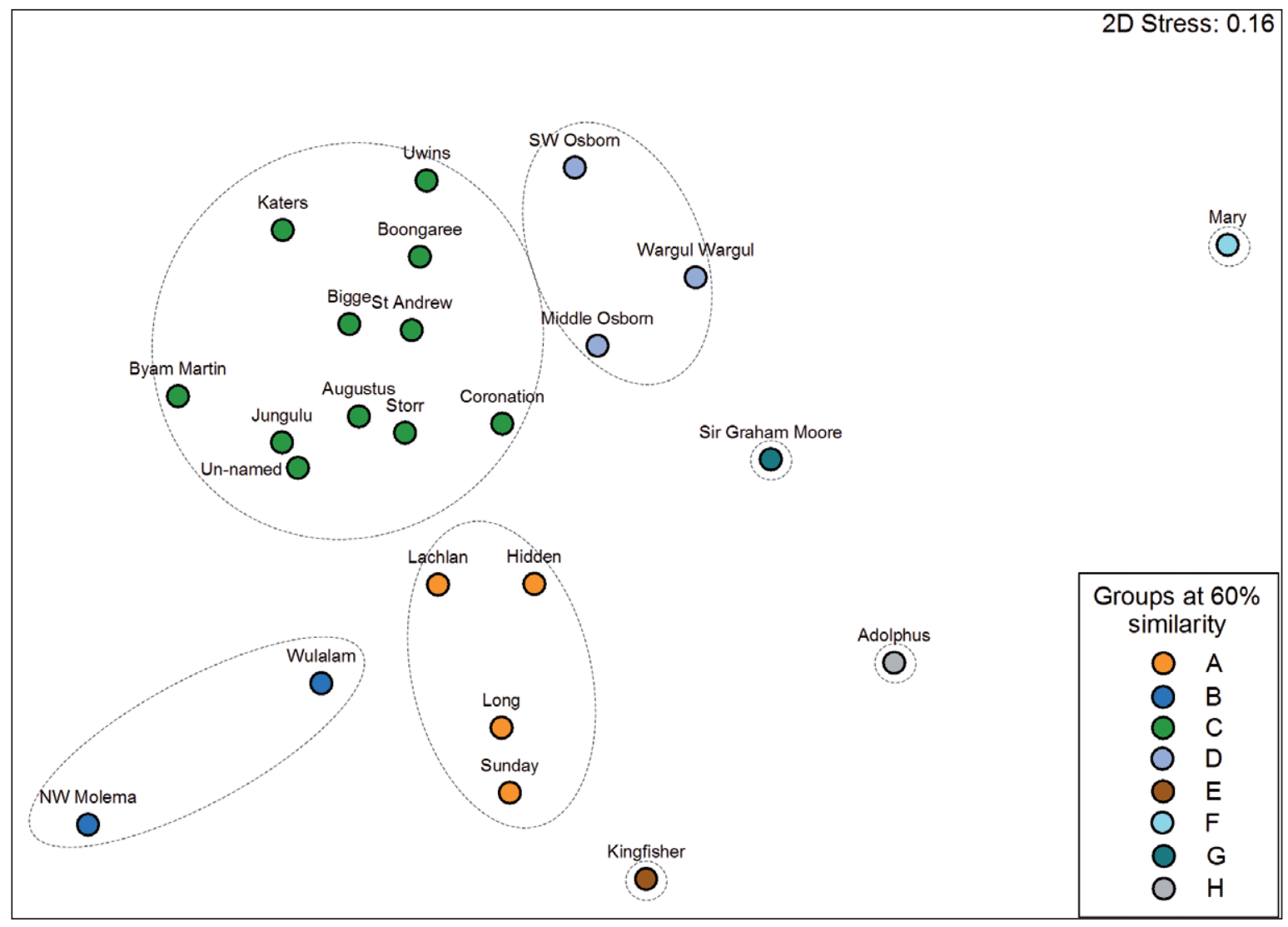

FIGURE 3 A non-metric multi-dimensional scaling ordination showing association among islands based on reptile occurrence. Groups are defined by indicator species analysis at the $60 \%$ similarity level (dashed lines).

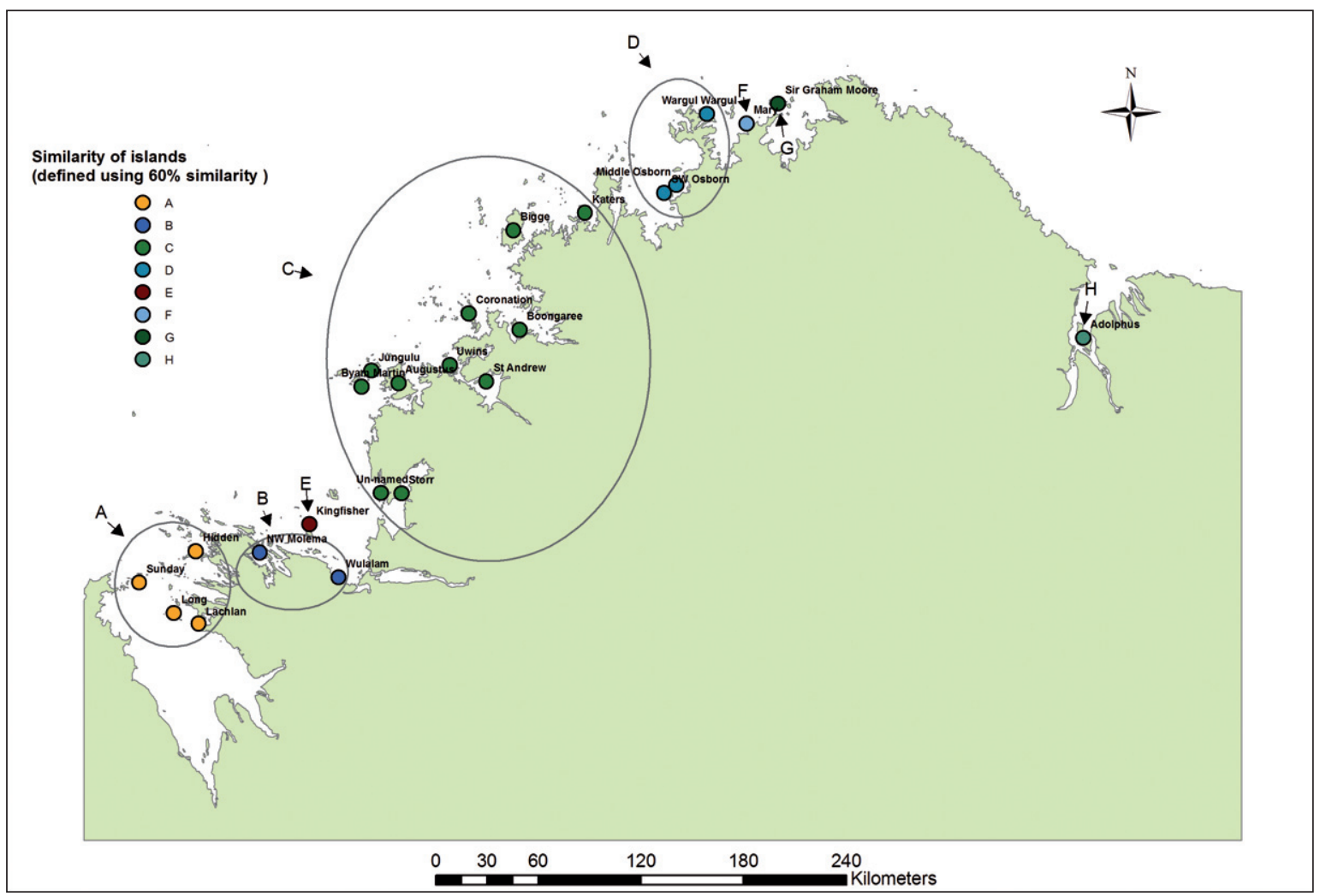

FIGURE 4 Map of the geographic clustering of island groups based on reptile species occurrence. 
sharing numerous species that prefer sandy habitat. Species richness of Kingfisher was also relatively low with only 16 species, which may explain why it is an outlier.

\section{ISLAND ATTRIBUTES AND SPECIES ASSEMBLAGES}

The BEST analysis of the eight island attributes we tested showed strong correlations (Spearman's rho $=0.53$ ) between the observed reptile assemblages and three variables: 1) presence of rugged outcropping rock ('boulder'), 2) mean annual rainfall, and 3) maximum temperature in the warmest period of the year (mxTwmP). These attributes are reflected by the clusters identified by the mNDS ordination (Figure 3).

Species similarity of the reptiles among islands decreased significantly with geographical distance from each other (Mantel $r=-0.535, P<0.01$ ). When we corrected for the effect of geographical distance, the correlation of species similarity with boulder presence remained significant (Mantel $\mathrm{r}=-0.473$, $P<0.01)$, although the correlation with annual average rainfall and maximum temperature in the warmest period did not. This result suggests that geographic distance and the climate attributes contribute to the pattern observed; however, their relative importance is difficult to interpret.

\section{DISCUSSION}

The Kimberley islands have a rich and varied reptile fauna that encompasses all of the major terrestrial families in the Australian herpetofauna. The known terrestrial reptile fauna for all Kimberley islands is currently 87 species, which is more than on other island groups of Australia's tropics, such as in the Wessel and English Company island group off the Arnhem Land coast (44 species; Woinarski et al. 1999), or the Torres Strait islands (62 species; Lavery et al. 2012). The islands of the Pilbara region harbour an estimated 71 species of reptile (Bamford et al. 2005; Richardson et al. 2006; WAM records). We detected 79 species on the 24 islands we surveyed. The seven native taxa we did not record were Ramphotyphlops yampiensis, Diplodactylus conspicillatus and Gehyra aff. nana sp. B known from Koolan Island, Lerista praefrontalis from King Hall Island (although see Maryan and Robinson [1997] for doubts about the validity of this species), Lophognathus aff. gilberti from Lesueur Island, Cyrtodactylus kimberleyensis from East Montalivet Island and Lerista sp. from Colbert Island. All these taxa are known from records for single islands based on one or two voucher specimens. The introduced Asian House Gecko (Hemidactylus frenatus) is known to occur on Adele, Browse and Troughton islands.

The Northern Kimberley is an area of high reptile diversity and endemism, with 126 named reptile taxa and about 23 undescribed taxa (WAM records and recent molecular investigations mentioned above). Of these, 42 taxa are endemic to the region, with 33 known from at least one island. The majority of these endemics occur on the islands in the higher rainfall zone (>1000 mm p.a.; Figure 1) of the north-west Kimberley. Included in these counts were 10 species (Cyrtodactylus kimberleyensis, Ramphotyphlops sp. A and sp. B, R. yampiensis, Lerista praefrontalis, Lerista sp., and Crenadactylus Kimberley C, E, F and G) not currently known on the adjacent mainland. These are unlikely to be true insular endemics as they are present on near-shore islands. Rather, it probably indicates the lack of sampling of the herpetofauna along the Kimberley coastline (McKenzie et al. 2009).

Reptile richness increased with island size, as was the case for similar continental-shelf archipelagos (Woinarski et al. 1999; Lavery et al. 2012). The two largest islands in the Kimberley, Augustus (18,929 ha) and Bigge (17,108 ha), have 31 species known on each. Comparatively, Koolan Island (2509 ha and $0.7 \mathrm{~km}$ offshore) has 39 and Barrow Island (23,503 ha and $54 \mathrm{~km}$ offshore) in the neighbouring Pilbara region has 43 reptile species (McKenzie et al. 1995; Bamford et al. 2005; Maryan and Reinhold 2009). Both of these islands have a long history of reptile survey related to mining activity, which suggests that further survey effort on the islands we surveyed will result in an increase of the number of species detected.

\section{REPTILE ASSEMBLAGES IN RELATION TO ISLAND ATTRIBUTES}

Geographical location was the most important determinant of reptile assemblages on the Kimberley islands, with similarity in species assemblages decreasing with increasing distance between the islands. While some of this pattern is likely explained by limits to dispersal, the spatial auto-correlation between geographic distance and mean annual rainfall and maximum temperature in the warmest periods, suggested that climatic gradients at a regional scale are an important influence on reptile communities. In particular, the distinct rainfall gradient has effects on vegetation structure and habitat complexity (McKenzie et al. 1991).

Greatest species richness, including richness of regional endemic taxa, was concentrated on the wettest (>1000 mm mean annual rainfall), warmest and also mostly larger islands located in the north-west Kimberley (i.e. cluster C). These cluster $\mathrm{C}$ islands also tend to contain the rugged, rocky habitat that was found to be the only significant local-scale factor strongly correlated with species assemblages. Here, the Warton and King Leopold 
TABLE 3 Indicator species values for the four island clusters containing multiple islands (cluster A to D). Only species with a significant value of $P \leq 0.05$ are reported and highest indicator values are in bold. Key: $\wedge$ taxa endemic to the Northern Kimberley.

\begin{tabular}{|c|c|c|c|c|c|}
\hline Species & Cluster A & Cluster B & Cluster C & Cluster D & $P$-value \\
\hline Varanus glebopalma & 47 & 0 & 21 & 6 & 0.008 \\
\hline Notoscincus ornatus & 51 & 0 & 19 & 12 & 0.012 \\
\hline Demansia quaesitor & 0 & 100 & 0 & 0 & 0.005 \\
\hline Carlia amax & 0 & 85 & 3 & 0 & 0.016 \\
\hline Acanthophis praelongus & 0 & 85 & 3 & 0 & 0.016 \\
\hline Crenadactylus Kimberley $\mathrm{E}^{\wedge}$ & 17 & 67 & 0 & 0 & 0.041 \\
\hline Gehyra multiporosa^ ${ }^{\wedge}$ & 0 & 0 & 91 & 0 & 0.001 \\
\hline Carlia johnstonei^ ${ }^{\wedge}$ & 0 & 0 & 50 & 50 & 0.001 \\
\hline 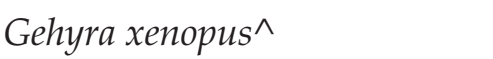 & 0 & 0 & 52 & 28 & 0.005 \\
\hline Amalosia obscura^ ${ }^{\wedge}$ & 19 & 0 & 51 & 0 & 0.022 \\
\hline Gehyra nana & 0 & 0 & 0 & 100 & 0.001 \\
\hline Heteronotia binoei $\mathrm{NWK}^{\wedge}$ & 0 & 0 & 43 & 52 & 0.001 \\
\hline Cryptoblepharus megastictus ${ }^{\wedge}$ & 0 & 0 & 0 & 67 & 0.021 \\
\hline
\end{tabular}

sandstones reach their greatest heights and complexity with fracturing, cliff collapses, boulders and scree slopes providing a rich variety of habitats. The ruggedness of these islands, coupled with the higher rainfall, allows the persistence of many patches of monsoon rainforest, in part due to water seepage along the base of sandstone cliffs, but also due to a shielding effect from fire (ClaytonGreene and Beard 1985). The monsoon rainforest patches also tend to develop extensive leaf litter beds. As a consequence, the reptile faunas of islands in this cluster are dominated by saxicoline species associated with screes, cliffs, gorges and/ or caves (e.g. Gehyra xenopus, G. multiporosa), but also a number of species that forage in leaf litter (e.g. Carlia johnstonei) or in loose soils associated with rocks (e.g. Lerista walkeri and Ramphotyphlops $\mathrm{sp}$. B). All of the 12 widely occurring generalist taxa (present on $\geq 15$ islands; see Appendix 2) were found on the majority of islands in this cluster. Regional endemics were also well represented, with 21 taxa recorded -14 of which were unique to islands in cluster C. Some were restricted range taxa and were only recorded on a single island or a subset of islands (2-4, usually neighbouring islands). Examples include Ctenotus burbidgei, Diporiphora superba, Lerista walkeri and Pogona microlepidota. Species richness was elevated by greater species 'packing' in some genera; for example, three species of Gehyra were detected on most islands in this cluster. Some of these islands were also found to have three species of Carlia or python, and two species of Ctenotus.

The island cluster furthest north (cluster D) shared many reptile species with cluster C, including all of the 12 widespread species and the indicator species Heteronotia binoei NWK. Species turnover, however, was apparent between these clusters with congeneric replacement occurring in Gehyra multiporosa by G. nana and Amalosia obscura by $A$. rhombifera. A number of species (e.g. agamids, Crenadactylus spp. and Gehyra aff. nana sp. A) associated with the sandstone habitats of cluster C were not detected on the predominantly volcanic islands of this northern cluster.

The islands immediately to the south of cluster C, NW Molema and Wulalam (cluster B), have lower mean annual rainfall $(<905 \mathrm{~mm})$ and less rugged sandstone habitats than the islands in cluster C. Substantial species compositional differences were found between these two island groups, resulting from both a high level of species turnover and numerous species losses. Congeneric species replacements occurred across multiple taxa, including Crenadactylus Kimberley C by Crenadactylus Kimberley E, and Gehyra multiporosa by G. occidentalis. Species losses were mostly in the high-rainfall zone endemics (e.g. Gehyra xenopus and Heteronotia binoei NWK) and specialist rainforest taxa such as $C$. johnstonei 
(although C. amax appears to occupy a similar ecological niche to C. johnstonei). NW Molema and Wulalam islands also lacked several widespread species (e.g. Lialis burtonis and Varanus glebopalma) and they were depauperate in skinks and geckos (Diplopactylidae and Gekkonidae). The presence of the two widespread species above and a speciesrich skink and gecko fauna on the nearby, larger Koolan Island (Maryan and Reinhold 2009), suggests these absences were probably a result of low survey effort. Both these islands were surveyed for the first time during our study. Demansia quaesitor was also unique to cluster $B$.

The four islands in the southern-most cluster (cluster A) were distinguished by the occurrence of southern Kimberley and arid-zone taxa, and the lack of taxa that appear to be restricted to the highrainfall islands. For example, species including Gehyra occidentalis, Heteronotia binoei KA6-C, Lerista greeri and L. griffini, were largely absent from the higher rainfall islands in clusters $C$ and $D$, but were found on these southern, drier islands $(<850 \mathrm{~mm})$. All 12 widespread taxa, however, were present on islands in this cluster. Few elapids were found on islands in Cluster D.

The remaining islands had different combinations of habitat attributes that were reflected in the observed species assemblages. Adolphus Island lies well to the east of all the other islands in a comparatively low rainfall zone $(827 \mathrm{~mm})$, and while rocky, it lacks the highly dissected landforms of other islands, and it has the highest maximum temperatures. It was the only island surveyed in the Berkeley sub-region of the Northern Kimberley. Its reptile assemblage lacked the Northern Kimberley saxicoline endemics but included a variety of species from the drier, warmer habitats typical of the mainland east Kimberley, such as Gehyra koira, Ctenotus robustus and Varanus p. panoptes. Mary Island supported a number of widespread generalist taxa, but it is a predominantly sand island and accordingly lacked many of the common saxicoline taxa. It also shared a number of restricted range endemics with Sir Graham Moore Island, two of which are sand specialists. Sir Graham Moore Island, which had a comparatively high species richness of 29 taxa, possesses a range of substrates, including sandstone, but also extensive areas of Quaternary sands that support taxa more typical of the drier Kimberley mainland, such as Ctenotus mesotes. Kingfisher Island was species poor, lacking Northern Kimberley endemics as well as Heteronotia planiceps, which is present on drier islands along the coastline. Unique to Kingfisher was Gehyra aff. koira, which was found on the trunk of a Northern Salmon Gum (Eucalyptus bigalerita). This was the only island where this smooth barked gum was recorded. Another unique feature of Kingfisher Island's gecko fauna was the presence of a dwarf form of Gehyra occidentalis (Doughty et al. 2012a).

\section{COMPARISON WITH KIMBERLEY MAINLAND HERPETOFAUNA}

A number of taxa that are widespread and/ or relatively common on the adjacent mainland were either rarely recorded or not recorded on the islands. These taxa were usually large predatory species, arboreal or wetland/watercourse taxa. High-trophic level taxa absent or rare on the islands were large-bodied goannas (Varanus gouldii, $V$. mertensi, V. mitchelli, V. p. panoptes), large-bodied boids (Aspidites melanocephalus, Liasis fuscus, M. spilota variegata) and the large elapid snake Pseudechis australis. The largest-bodied geckos ( 100 $\mathrm{mm}$ snout-vent length) of the Kimberley region (Oedura filicipoda, Pseudothecadactylus cavaticus [a single record] and Nephrurus sheai) were also largely missing from the islands, even when their preferred habitat-large areas of steep and dissected outcropping sandstone-was present. An exception to the absence of large-bodied predators was the Olive Python (Liasis o. olivaceaus), which was found on many of the larger islands, but has also been recorded on some small islands such as Don Island (70 ha and $26 \mathrm{~km}$ offshore; How et al. 2006). Olive Pythons are very capable swimmers and they are known to board moored vessels up to $0.7 \mathrm{~km}$ off the coast at night (C. Tucker, pers. comm.), which suggests regular movement between islands by this species.

With the exception of a few records of Diporiphora and Pogona microlepidota, agamid dragons are not well represented on Kimberley islands. Largebodied arboreal or partly arboreal species such as Lophognathus gilberti, Chlamydosaurus kingii and Chelosania brunnea were absent on the islands. Similarly, the arboreal goannas Varanus scalaris and $V$. tristis, which are relatively abundant on the mainland across the monsoonal tropics, were not detected on the islands. While the fire history of the islands is unknown, the absence of largebodied arboreal species on the Kimberley islands may be due to insufficient time between intense fires for recolonisation from the mainland to occur, even though arboreal species are those most likely to recolonise from the mainland via floating vegetation 'rafts'.

Also absent from the islands were the goannas Varanus mertensi and V. mitchelli, the snakes Liasis fuscus and Tropidonophis $m$. mairii and freshwater turtles, all of which are typically associated with permanent fresh water. Only the largest island, Augustus, is of sufficient size and with varied enough topography to maintain enough freshwater habitats through the dry season for mesic 
species such as $V$. mertensi. Woinarski et al. (1999) also attributed the absence of such species from the Arnhem Land islands they sampled to lack of available fresh-water habitat.

\section{ADEQUACY OF SAMPLING}

Island archipelagos are typically challenging places to sample herpetofauna. Difficult access and logistics often limit sampling time and effort. Furthermore, reptiles use a wide range of shelter sites and foraging strategies and so have differing likelihoods of detection depending on the survey techniques employed. In our survey, we relied primarily on funnel traps and on active searching by day (including raking of litter, and rolling rocks and logs), and searching at night with headtorches. A few taxa were captured in Elliott traps set for mammals or uncovered under scree during land snail surveys. Although the use of pitfall traps would likely have resulted in the capture of further taxa, the predominantly rocky nature of the islands largely precluded their use. Nonetheless, future island surveys could make use of pitfalls for sampling reptile faunas, especially in Quaternary sands (coastal dunes and flats) and on alluvial terraces alongside watercourses. We found Lerista spp. persisting in small areas of Quaternary sands on numerous islands. Additionally, more extensive wet season sampling of herpetofauna should be considered in any future island surveys.

\section{CONSERVATION IMPLICATIONS}

The Kimberley islands are home to species-rich and diverse reptile assemblages that are currently little affected by human-induced changes. The Northern Kimberley has been identified as one of Australia's 15 'National Biodiversity Hotspots' (SEWPaC 2012), largely on account of its landscapes and endemic mammals. The Northern Kimberley herpetofauna also deserves recognition due to its high levels of endemism and the novel species assemblages found on its islands. The largest islands in the most mesic section of the coast (cluster C) are particularly significant. They have higher species richness than islands in drier tracts of the Kimberley coastline and harbour many Northern Kimberley endemics. Nonetheless, other islands have distinct assemblages that are not represented in cluster $C$ due to species turnover along the archipelago, and are also deserving of special consideration. Regional and endemic species with restricted ranges account for a considerable proportion of the reptile diversity in the Northern Kimberley and, due to their limited geographic range, potentially face greater extinction risk from the arrival of novel predators or competitors than more widespread taxa. Additionally, this group of species may have narrow climatic tolerances and be vulnerable to rapid anthropogenic climate change (Oliver et al. 2010).

The Asian House Gecko (Hemidactylus frenatus) is the only known reptile introduced to the Kimberley islands, although it is common in towns and communities on the adjacent mainland (Hoskin 2011). When sympatric with native gecko species in urban environments, it is typically the most aggressive and is likely to displace them (Csurhes and Markula 2009), although it may be competitively subordinate to larger native species such as Gehyra australis (Yang et al. 2012). Stringent quarantine protocols have been developed for operations on Barrow Island (Chevron 2011) and these could be adapted for use on Kimberley islands in conjunction with an education campaign targeting tourist operations, Aboriginal communities and the resource industry.

A greater invasion risk with more devastating impacts is likely posed by the arrival of the Cane Toad. Ingestion of toads is a serious threat for many predators that regularly eat frogs and that may have relatively small population sizes on islands, such as the goannas Varanus acanthurus, $V$. glauerti, V. gouldii, V. mertensi and V. glebopalma. The large-bodied skink Tiliqua scincoides intermedia is particularly susceptible to toads (Price-Rees et al. 2010). Elapid snakes are also at considerable risk, so islands with populations of known susceptible species such as A. praelongus, Demansia papuensis and Pseudechis weigeli (B. Phillips, J. Webb, DJP, R. Shine, unpublished data) require careful quarantine procedures and monitoring to enable, where practicable, quick eradication of toads if they arrive. The viability of islands as refuges for reptile species susceptible to lethal ingestion of Cane Toads will be dependent on their location relative to river mouths. Woinarski et al. (2011) reported that Cane Toads colonised most islands in the Sir Edward Pellew Group in the Gulf of Carpentaria following a major flood event in the McArthur River in 2002. Adolphus, Boongaree, St Andrew, Uwins and Storr Islands all lie, either close to, or in the mouths of major tropical river systems.

Unmanaged, frequent and intense fires are likely to pose a significant threat to reptile communities, particularly those of woodlands, by changing vegetation structure and productivity and exposing species to increased predation. Current fire regimes on the Kimberley islands vary markedly, depending on the extent and type of human visitation (O'Connor 1999), but no specific information on Aboriginal burning of the islands is available. Lightning-ignited fires usually occur in the early wet season, but the size of these fires may be limited by rain associated with thunderstorms or 
by areas of rugged or wet habitats. Dry season fires have the potential to burn entire islands. Future fire management should aim to maintain habitat complexity by creating a mosaic of regenerating and mature habitat, while protecting fire-sensitive vegetation and minimizing topsoil loss.

\section{ACKNOWLEDGEMENTS}

The surveys involved many people and we wish to thank our colleagues from the Department of Environment and Conservation, Western Australian Museum, Kimberley Land Council, Roy Teale of Biota Environmental Sciences, the participating Traditional Owners, Aboriginal Rangers and base camp volunteers. We thank the skippers and crew of $M V$ Kimberley Escape, $M V$ Odyssey and pilots from Heliwork and Broome Helicopters for transporting teams safely on and off islands. We are grateful to the DEC Kimberley regional manager, Darryl Moncrieff and the staff in the Kununurra and Broome offices for their support during the project. DEC rangers at Mitchell River National Park, Lindsey Baker and John Hayward, provided valuable logistic support. The project was possible through a research agreement with the Kimberley Land Council for the Balanggarra, BardiJawi, Dambimangari, Mayala and Uunguu native title claim groups. Thanks also to Viki Cramer, Tom Vigilante, Lesley Gibson and two anonymous reviewers for comments on the manuscript. Funding was provided by the Natural Heritage Trust and DEC.

\section{REFERENCES}

Abbott, I. and Burbidge, A.A. (1995). The occurrence of mammal species on the islands of Australia: a summary of existing knowledge. CALMScience $\mathbf{1}$ : 259-324.

Bamford, M.J., Bamford, A.R., Biota Environmental Sciences and RPS Bowman Bishaw Gorham (2005). Gorgon development on Barrow Island: technical report: mammals and reptiles. Prepared for ChevronTexaco Australia Pty Ltd. http:/ / www.chevronaustralia.com/ Libraries/Chevron_Documents /C2_Mammals_and_ Reptiles.pdf.sflb.ashx

Basedow, H. (1918). Narrative of an expedition of exploration in north-western Australia. Proceedings of the Royal Geographical Society of Australasia, South Australian Branch 18: 105-295.

Bauer, A.M. and Doughty, P. (2012). A new bent-toed gecko (Squamata: Gekkonidae: Crytodactylus) from the Kimberley region, Western Australia. Zootaxa 3187: 32-42.

Beard, J.S. (1979). The vegetation of the Kimberley area: explanatory notes to sheet 1 . University of Western Australia Press: Perth.

Bowman, D.M.J.S., Brown, G.K., Braby, M.F., Brown, J.R ., Cook, L.G., Crisp, M.D., Ford, F., Haberle, S., Hughes, J., Isagi, Y., Joseph, L., McBride, J., Nelson, G. and Ladiges, P.Y. (2010). Biogeography of the Australian monsoon tropics. Journal of Biogeography 37: 201-216.

Bureau of Meterology (2012). Climate and past weather for Australia. www.bom.gov.au/climate/. Accessed 15 March 2012.

Burbidge, A.A. and McKenzie, N.L. (1978). The islands of the north-west Kimberley: Western Australia. Wildlife Research Bulletin Western Australia No. 7. Department of Fisheries and Wildlife: Perth.

Calsbeek, R. and Smith, T.B. (2003). Ocean currents mediate evolution in island lizards. Nature 426: 552-555.

Case, T.J. (1975). Species numbers, density compensation, and colonizing ability of lizards on islands in the Gulf of California. Ecology 56: 3-18.

Case, T.J. (2002). Reptiles (pp 221-270). In: Case, T.J., Cody, M.L. and Ezcurra, E. (eds), A new island biogeography of the Sea of Cortés. Oxford Univeristy Press: New York.

Clarke, K.R. and Gorley, R.N. (2006). PRIMER v6: User manual/tutorial. Primer-E, Ltd: Plymouth, U.K.

Clayton-Greene, K.A. and Beard, J.S. (1985). The fire factor in vine thicket and woodland vegetation in the Admiralty Gulf region, northwest Kimberley, Western Australia. In: Ridpath, M.G. and Corbett, L.K. (eds) Ecology of the Wet-Dry Tropics. Proceedings of the Ecological Society of Australia 13: 225-230.

Conservation Council of Western Australia (2010). Status performance assessment: biodiversity conservation on Western Australian Islands. Phase II - Kimberley islands. Conservation Commission of Western Australia Final Report. Western Australia Government: Perth.

Chevron Australia Pty Ltd (2011). Barrow Island Quarantine: Terrestrial and Marine Quarantine Management System. http://www.chevronaustralia. com / Libraries / Chevron_Documents / Gorgon_ Project_Terrestrial_and_Marine_Quarantine_ Management_System.pdf.sflb.ashx. Accessed 23 July 2012.

Cracraft, J. (1991). Patterns of diversification within continental biotas: hierarchical congruence among the areas of endemism of Australian vertebrates. Australian Systematic Botany 4: 211-227.

Crawford, I.M. (2001). We won the victory: Aborigines and outsiders on the north-west coast of the Kimberley. Fremantle Arts Centre Press: Fremantle.

Cresswell, G.R. and Badcock, K.A. (2000). Tidal mixing near the Kimberley coast of NW Australia. Marine and Freshwater Research 51: 641-646.

Csurhes, S. and Markula, A. (2009). Pest risk assessment: Asian house gecko, Hemidactylus frenatus. Queensland Primary Industries and Fisheries: Brisbane.

De Deckker, P. and Yokoyama, Y. (2009). Micropalaeontological evidence for Late Quaternary sealevel changes in Bonaparte Gulf, Australia. Global and Planetary Change 66: 85-92.

Doody, J.S., Green, B., Rhind, D., Castellano, C.M., Sims, R. and Robinson, T. (2009). Population-level declines in Australian predators caused by an invasive species. Animal Conservation 12: 46-53.

Doughty, P., Palmer, R., Sistrom, M.J., Bauer, A.M. and Donnellan, S.C. (2012a). Two new species of Gehyra geckos from the north-west Kimberley region of 
Western Australia. Records of the Western Australian Museum 27: 117-134.

Doughty, P., Palmer, R., Cowan, M. and Pearson, D.J. (2012b). Biogeography of frogs of the Kimberley islands, Western Australia. Records of the Western Australian Museum, Supplement 81: 109-124.

Dufrêne, M. and Legendre, P. (1997). Species assemblages and indicator species: the need for a flexible asymmetrical approach. Ecological Monographs 67: 345-366.

Fattorini, S. (2010). Influence of recent geography and paleogeography on the structure of reptile communities in a land-bridge archipelago. Journal of Herpetology 44: 242-252.

Ficetola, G.F. and Padoa-Schioppa, E. (2009). Human activities alter biogeographical patterns of reptiles on Mediterranean islands. Global Ecology and Biogeography 18: $214-222$

Gibson, L.A. and McKenzie, N.L. (2012a). Identification of biodiversity assets on selected Kimberley islands: background and implementation. Records of the Western Australian Museum, Supplement 81: 1-14.

Gibson, L.A. and McKenzie, N.L. (2012b). Occurrence of non-volant mammals on islands along the Kimberley coast of Western Australia. Records of the Western Australian Museum, Supplement 81: 15-39.

Hice, C.L. and Schmidly, D.J. (2002). The mammals of coastal Texas: a comparison between mainland and barrier island faunas. The Southwestern Naturalist 47: 244-256.

Horner, P. (2005). Gehyra koira sp. nov. (Reptilia: Gekkonidae), a new species of lizard with two allopatric subspecies from the Ord-Victoria region of north-western Australia and a key to the Gehyra australis species complex. The Beagle 21: 165-174.

Horner, P. (2007). Systematics of the snake-eyed skinks, Cryptoblepharus Wiegmann (Reptilia: Squamata: Scincidae): an Australian-based review. The Beagle, Supplement 3: 21-198.

Horner, P. (2009). Three new species of Ctenotus (Reptilia: Sauria: Scincidae) from the Kimberley region of Western Australia, with comments on the status of Ctenotus decaneurus yampiensis. Records of the Western Australian Museum 25: 181-199.

Hoskin, C.J. (2011). The invasion and potential impact of the Asian house gecko (Hemidactylus frenatus) in Australia. Austral Ecology 36: 240-251.

Houlder, D.J., Hutchinson, M.F., Nix, H.A. and McMahon, J.P. (2000). ANUCLIM user guide, version 5.1. Centre for Resource and Environmental Studies, Australian National University: Canberra.

How, R., Schmitt, L., Teale, R. and Cowan, M. (2006). Appraising vertebrate diversity on Bonaparte Islands, Kimberley, Western Australia. Western Australian Naturalist 92: 92-110.

How, R.A. and Cowan, M.A. (2006). Collections in space and time: geographical patterning of native frogs, mammals and reptiles through a continental gradient. Pacific Conservation Biology 12: 111-133.

How, R.A. and Kitchener, D.J. (1997). Biogeography of Indonesian snakes. Journal of Biogeography 24: 725-735.

Kendrick, P.G. and Rolfe, J.K. (1991). The reptiles and amphibians of Kimberley rainforests (pp 347-359). In: McKenzie, N.L., Johnston, R.B. and Kendrick, P.G (eds), Kimberley rainforests of Australia. Surrey Beatty: Sydney.

Kuch, U., Keogh, J.S., Weigel, J., Smith, L.A. and Mebs, D. (2005). Phylogeography of Australia's king brown snake (Pseudechis australis) reveals Pliocene divergence and Pleistocene dispersal of a top predator. Naturwissenschaften 92: 121-127.

Lavery, T.H., Watson, J.J. and Leung, L.K.P. (2012). Terrestrial vertebrate richness of the inhabited Torres Strait Islands, Australia. Australian Journal of Zoology 60: 180-191.

Legendre, P. and Legendre, L. (1998). Numerical ecology. Elsevier Science: New York.

MacArthur, R.H. and Wilson, E.O. (1963). An equilibrium theory of insular zoogeography. Evolution 17: 373-387.

Magurran, A.E. (2004). Measuring biological diversity. Blackwell Science: Oxford.

Maryan, B. and Robinson, D. (1997). An insular population of Lerista griffini and comments on the identity of Lerista praefrontalis (Lacertilia: Scincidae). Western Australian Naturalist 21: 157-160.

Maryan, B. and Reinhold, L. (2009). Additions to the terrestrial herpetofauna of Koolan and Dirk Hartog Islands. Western Australian Naturalist 27: 18-24.

McCune, B. and Mefford, M.J. (1999). PC-ORD multivariate analysis of ecological data, version $5 . \mathrm{MjM}$ Software: Gleneden Beach, U.S.A.

McKenzie, N.L., Johnston, R.B. and Kendrick P.G. (1991). Kimberley rainforests of Australia. Surrey Beatty \& Sons: Chipping Norton, Australia.

McKenzie, N.L., Fontanini, L., Lindus, N.V. and Williams, M.R. (1995). Biological inventory of Koolan Island, Western Australia 2. Zoological notes. Records of the Western Australian Museum 17: 249-266.

McKenzie, N.L., Start, A.N., Burbidge, A.A., Kenneally, K.F. and Burrows, N.D. (2009). Protecting the Kimberley: a synthesis of scientific knowledge to support conservation management in the Kimberley region of Western Australia. Part B: Terrestrial environments. Department of Environment and Conservation: Perth. pp. 19-31. http://www.dec.wa.gov.au/component/option,com docman/task,doc_details/gid,3407/Itemid,2219/

Melville, J., Ritchie, E.G., Chapple, S.N.J., Glor, R.E. and Schulte, I.I. (2011). Evolutionary origins and diversification of dragon lizards in Australia's tropical savannas. Molecular Phylogenetics and Evolution 58: 257-270.

O'Connor, S. (1999). 30,000 years of Aboriginal occupation, Kimberley, north west Australia. ANH Publications: Canberra.

Oliver, P., Adams, M. and Doughty, P. (2010). Molecular evidence for ten species and Oligo-Miocene vicariance within a nominal Australian gecko species (Crenadactylus ocellatus, Diplodactylidae). BMC Evolutionary Biology 10: 386.

Oliver, P.M., Doughty, P. and Palmer, R. (2012). Hidden biodiversity in rare northern Australian vertebrates: the case of the clawless geckos (Crenadactylus, Diplodactylidae) of the Kimberley. Wildlife Research 39: 429-435.

Pepper, M., Doughty, P., Hutchinson, M.N. and Keogh, 
J.S. (2011a). Ancient drainages divide recent species in Australia's arid zone: morphological and multigene evidence for four new species of beaked geckos (Rhynchoedura). Molecular Phylogenetics and Evolution 610: 810-822.

Phillips, B.L., Greenlees, M.J., Brown, G.P. and Shine, R. (2009). Predator behaviour and morphology mediates the impact of an invasive species: Cane Toads and death adders in Australia. Animal Conservation 13: 53-59.

Pietsch, T.W., Bogatov, V.V., Amaoka, K., Zhuravlev, Y.N., Barkalov, V.Y., Gage, S., Takahashi, H., Lelej, A.S., Storozhenko, S.Y. and Minakawa, N. (2003). Biodiversity and biogeography of the islands of the Kuril Archipelago. Journal of Biogeography 30: 12971310.

Powney, G.D., Grenyer, R., Orme, C.D.L., Owens, I.P.F. and Meiri, S. (2010). Hot, dry and different: Australian lizard richness is unlike that of mammals, amphibians and birds. Global Ecology and Biogeography 19: 386-396.

Price-Rees, S.J., Brown, G.P. and Shine, R. (2010). Predation on toxic Cane Toads (Bufo marinus) may imperil bluetongue lizards (Tiliqua scincoides intermedia, Scincidae) in tropical Australia. Wildlife Research 37: 166-173.

R Development Core Team (2009). R: A language and environment for statistical computing. R Foundation for Statistical Computing, Vienna. URL: http://www.Rproject.org.

Richardson, J., Watson, G. and Kregor, G. (2006). The distribution of terrestrial vertebrate fauna in the Montebello Islands. Conservation Science Western Australia 5: 259-268.

Richman, A.D., Case, T.J. and Schwaner, T.D. (1988). Natural and unnatural extinction rates of reptiles on islands. The American Naturalist 131: 611-630.

SEWPaC (2012). Australia's 15 National Biodiversity Hotspots. http://www.environment.gov.au/ biodiversity / hotspots/national-hotspots.html. Accessed 16 March 2012.

Shine, R. (2010). The ecological impact of invasive Cane Toads (Bufo marinus) in Australia. The Quarterly Review of Biology 85: 253-291.

Sistrom, M.J., Hutchinson, M.N., Hutchinson, R.G. and Donnellan, S.C. (2009). Molecular phylogeny of Australian Gehyra (Squamata: Gekkonidae) and taxonomic revision of Gehyra variegata in southeastern Australia. Zootaxa 2277: 14-32.

Smith, K.L., Harmon, L.J., Shoo, L.P. and Melville, J. (2011). Evidence of constrained phenotypic evolution in a cryptic species complex of agamid lizards. Evolution 65: 976-992.

Smith, L.A. and Harold, G. (2011). The 1990 expedition to Camden Harbour, north-west Kimberley: Part 4 Reptiles. The Western Australian Naturalist 27: 265-267.
Smith, L.A. and Johnstone, R.E. (1978). Part V Amphibians and reptiles (pp 42-45). In: Burbidge, A.A. and McKenzie, N.L. (eds), The islands of the northwest Kimberley: Western Australia, No. 7. Department of Fisheries and Wildlife: Perth.

Smith, J.G. and Phillips, B.L. (2006). Toxic tucker: the potential impact of Cane Toads on Australian reptiles. Pacific Conservation Biology 12: 40-49.

Start, A.N., Burbidge, A.A., McKenzie, N.L. and Palmer, C. (2007). The status of mammals in the North Kimberley, Western Australia. Australian Mammalogy 29: 1-16.

Thackway, R. and Cresswell, I.D. (1995). An interim biogeographic regionalisation for Australia: a framework for establishing the national system of reserves. Australian Nature Conservation Agency: Canberra.

Vigilante, T. (2001). Analysis of explorers' records of Aboriginal landscape burning in the Kimberley region of Western Australia. Australian Geographical Studies 39: 135-155.

Vigilante, T., Toohey, J., Gorring, A., Blundell, V., Saunders, T., Mangolamara, S., George, K., Oobagooma, J., Waina, M., Morgan, K. and Doohan, K. (2013). Island country: Aboriginal connections, values and knowledge of the Western Australian Kimberley islands in the context of an island biological survey. Records of the Western Australian Museum, Supplement 81: 145-181.

Wheeler, M.C. and McBride, J.L. (2005). AustralianIndonesian monsoon (pp 125-173). In: Waliser, D. and Lau K.-M. (eds), Intraseasonal variability in the atmosphere-ocean climate system. Praxis Publishing/ Springer-Verlag: New York.

Wilson, S. and Swan, G. (2010). A complete guide to reptiles of Australia (third edition). Reed New Holland: Sydney.

Woinarski, J.C.Z., Horner, P., Fisher, A., Brennan, K., Lindner, D., Gambold, N., Chatto, R. and Morris, I. (1999). Distributional patterning of terrestrial herpetofauna on the Wessel and English Company Island groups, northeastern Arnhem Land, Northern Territory, Australia. Australian Journal of Ecology 24: 60-79.

Woinarski, J.C.Z., Ward, S., Mahney, T., Bradley, J., Brennan, K., Ziembicki, M. and Fisher, A. (2011). The mammal fauna of the Sir Edward Pellew island group, Northern Territory, Australia: refuge and death-trap. Wildlife Research 38: 307-322.

Yang, D., González-Bernal, E., Greenlees, M. and Shine, R. (2012). Interactions between native and invasive gecko lizards in tropical Australia. Austral Ecology 37: 592-599.

MANUSCRIPT RECEIVED JULY 2012; ACCEPTED APRIL 2013. 
APPENDIX 1 Values of the island environmental attributes used to examine reptile assemblage associations.

Key: Boulder - extent of rock scree $(0=$ flat; $1=$ rounded, soil-mantled hill slopes and plateaux, narrow scree; 2 = shallow joints, wide ledges, moderate scree; 3 = massive scree, deep joints and scarp country), Elevation - maximum elevation, Rivermouth - proximity to river mouth ( 1 to 5 increasing distance from major river mouth), Rainfall - mean annual rainfall; Distance - distance to the mainland (was log-transformed prior to analysis), Area - area of island (was log-transformed prior to analysis), $\mathrm{mxTwmP}$ - maximum temperature of the warmest period of the year, and TwrmQ - mean temperature of the warmest 3 monthly period of the year.

\begin{tabular}{lllllllll} 
Island & Boulder & $\begin{array}{l}\text { Elevation } \\
(\mathrm{m})\end{array}$ & Rivermouth & $\begin{array}{l}\text { Rainfall } \\
(\mathrm{mm})\end{array}$ & $\begin{array}{l}\text { Distance } \\
(\mathrm{km})\end{array}$ & $\begin{array}{l}\text { Area } \\
(\mathrm{ha})\end{array}$ & $\begin{array}{l}\mathrm{mxTwmP} \\
\left({ }^{\circ} \mathrm{C}\right)\end{array}$ & $\begin{array}{l}\text { Twrm0 } \\
\left({ }^{\circ} \mathrm{C}\right)\end{array}$ \\
\hline Adolphus & 2 & 244 & 1 & 827 & 1.96 & 4134 & 37.55 & 31.05 \\
Augustus & 3 & 181 & 4 & 1170 & 1.79 & 18,929 & 34.17 & 29.13 \\
Bigge & 3 & 138 & 3 & 1103 & 2.97 & 17,108 & 34.63 & 29.23 \\
Boongaree & 3 & 235 & 2 & 1138 & 0.14 & 4164 & 35.31 & 29.03 \\
Byam Martin & 3 & 69 & 5 & 1144 & 13.28 & 816 & 33.58 & 29.04 \\
Coronation & 2 & 153 & 5 & 1141 & 6.07 & 3791 & 34.84 & 29.19 \\
Hidden & 3 & 127 & 4 & 839 & 1.48 & 1871 & 33.19 & 29.27 \\
Jungulu & 3 & 95 & 5 & 1148 & 18.91 & 4803 & 33.90 & 29.29 \\
Katers & 3 & 101 & 4 & 1069 & 1.40 & 1713 & 35.00 & 29.20 \\
Kingfisher & 1 & 82 & 4 & 943 & 15.47 & 300 & 34.03 & 29.52 \\
Lachlan & 2 & 93 & 2 & 787 & 0.17 & 1150 & 33.92 & 29.32 \\
Long & 2 & 65 & 2 & 768 & 9.36 & 1125 & 33.97 & 29.53 \\
Mary & 0 & 11 & 4 & 968 & 0.68 & 847 & 34.46 & 29.51 \\
Middle Osborn & 2 & 240 & 4 & 1051 & 2.34 & 2378 & 34.54 & 28.81 \\
NW Molema & 2 & 154 & 3 & 881 & 1.06 & 592 & 33.38 & 29.22 \\
Sir Graham Moore & 1 & 61 & 4 & 979 & 2.84 & 2812 & 34.40 & 29.50 \\
St Andrew & 2 & 284 & 1 & 1127 & 2.23 & 1465 & 35.66 & 29.48 \\
Storr & 3 & 165 & 1 & 1007 & 0.26 & 1883 & 35.40 & 29.90 \\
Sunday & 2 & 59 & 3 & 778 & 8.06 & 1186 & 33.21 & 29.11 \\
SW Osborn & 3 & 134 & 4 & 1041 & 3.07 & 1340 & 34.81 & 28.99 \\
Un-named & 2 & 83 & 3 & 1000 & 0.69 & 897 & 35.18 & 29.90 \\
Uwins & 3 & 134 & 2 & 1155 & 0.23 & 3219 & 34.81 & 29.11 \\
Wargul Wargul & 1 & 87 & 4 & 946 & 0.25 & 626 & 33.67 & 29.24 \\
Wulalam & 1 & 77 & 2 & 901 & 0.86 & 415 & 35.26 & 29.96 \\
\hline
\end{tabular}


APPENDIX 2 Terrestrial reptile taxa known from the 24 surveyed Kimberley islands. Islands are grouped according to their similarities in their species co-occurrences.

Key: $\wedge$ taxa endemic to the Northern Kimberley IBRA region; * new records of species arising from this survey for all Kimberley islands; + (bold type) = species previously detected but not during the current survey.

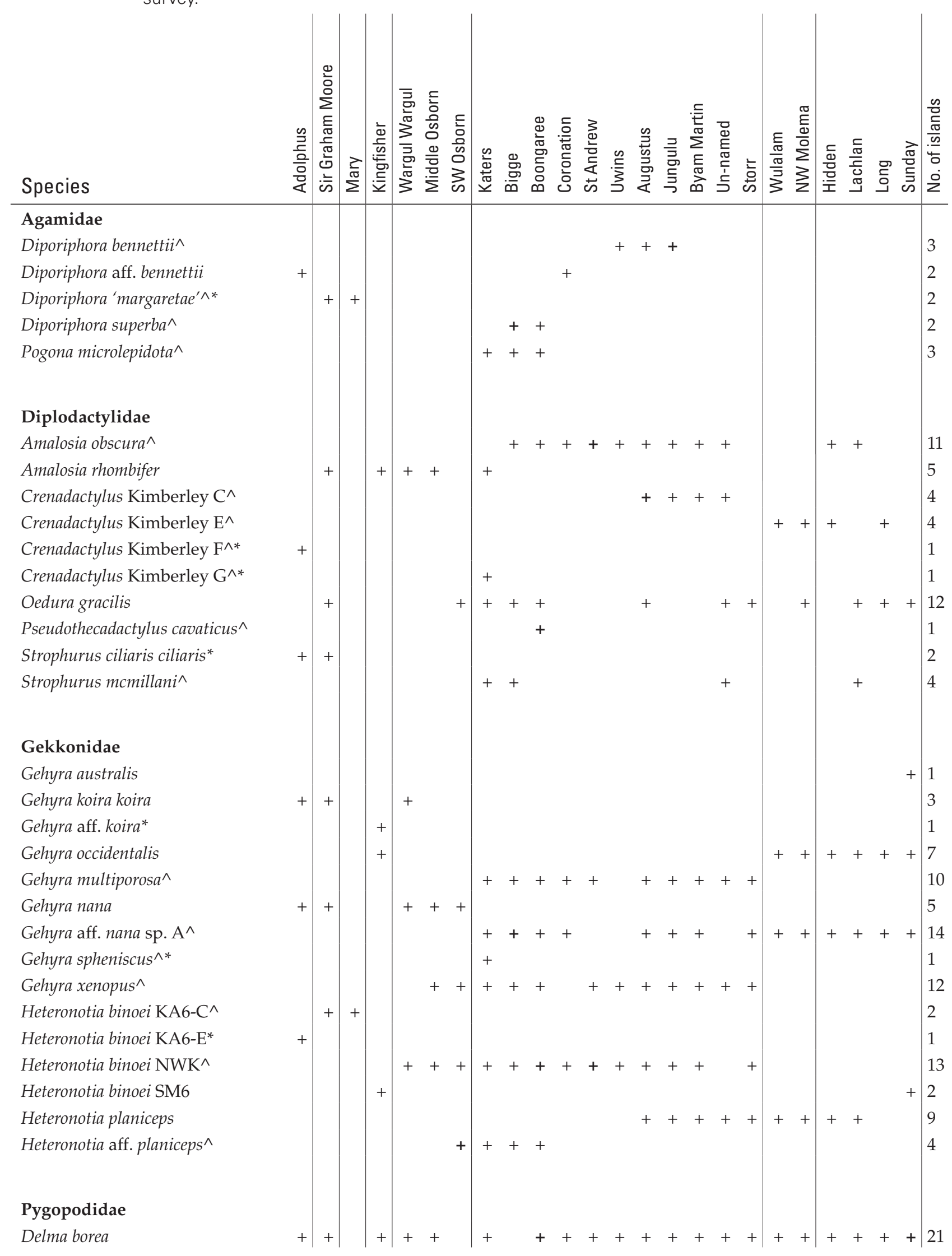




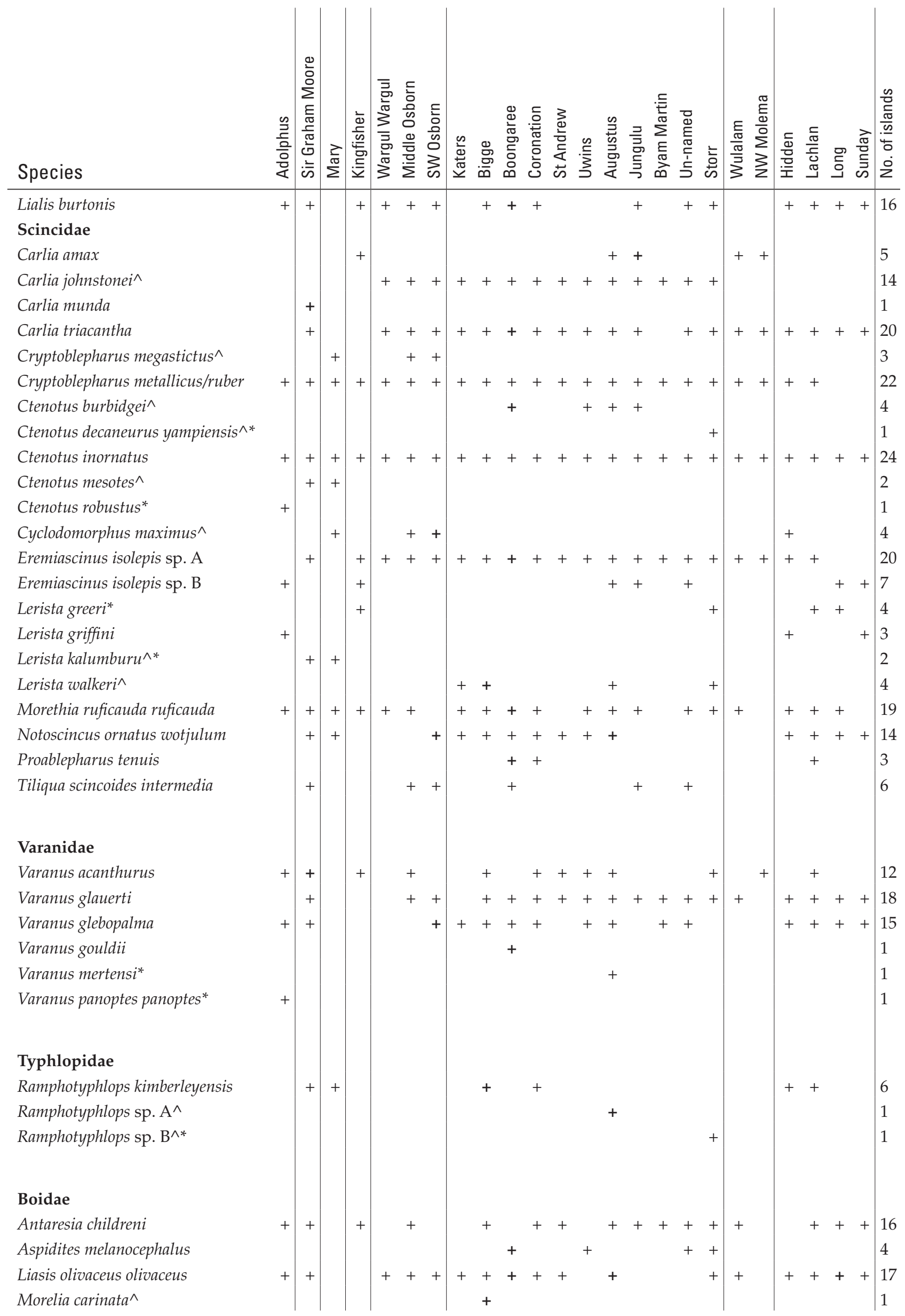




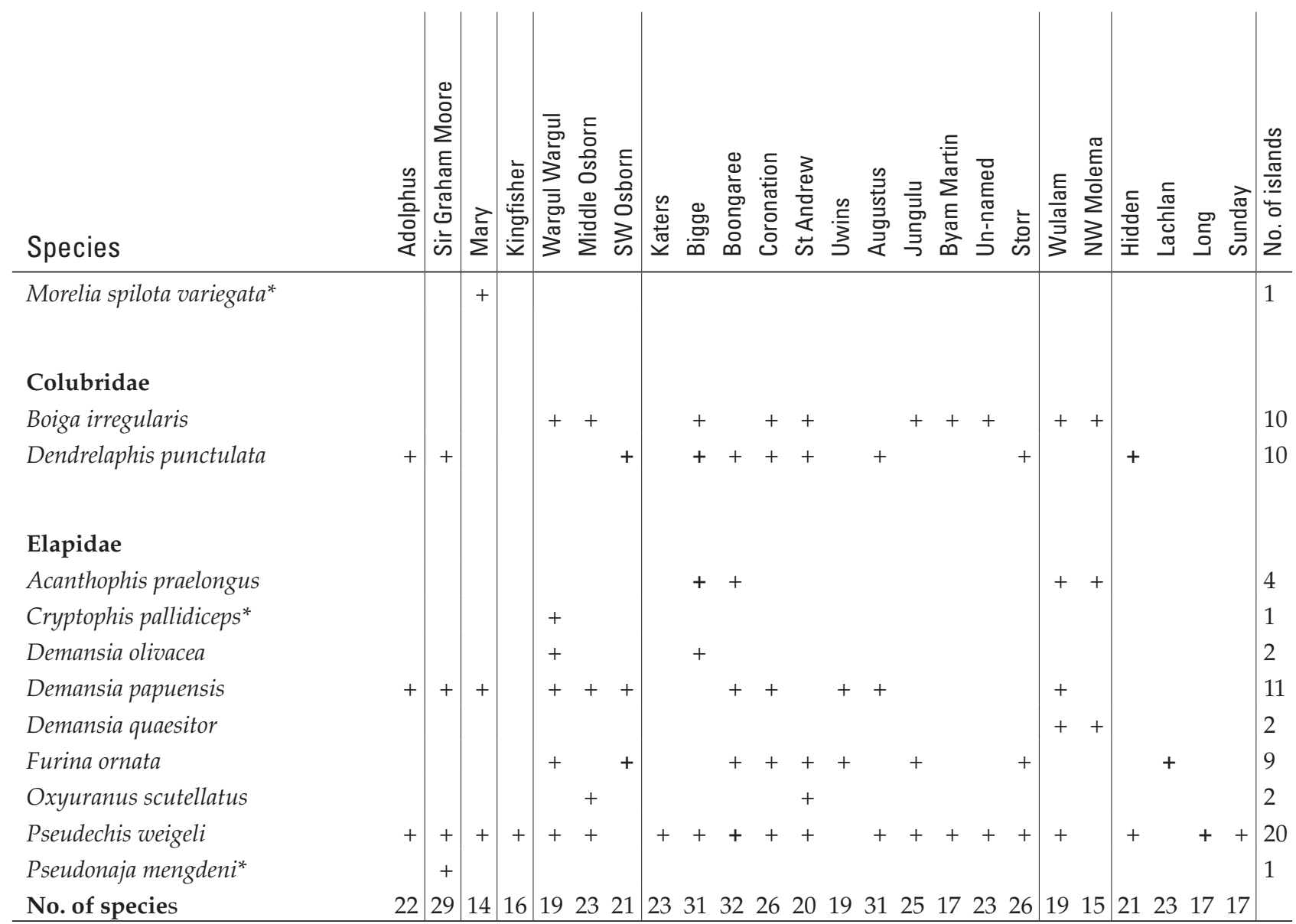

